\title{
A Decade After the 2004 Indian Ocean Tsunami: The Progress in Disaster Preparedness and Future Challenges in Indonesia, Sri Lanka, Thailand and the Maldives
}

\author{
Anawat Suppasri, ${ }^{1}$ Kazuhisa Goto, ${ }^{1}$ Abdul Muhari, ${ }^{2}$ Prasanthi Ranasinghe, ${ }^{3}$ Mahmood Riyaz, ${ }^{4}$ \\ MuZailin Affan, ${ }^{5}$ Erick Mas, ${ }^{1}$ Mari Yasuda, $^{1}$ and Fumihiko Imamura ${ }^{1}$
}

\begin{abstract}
The 2004 Indian Ocean tsunami was one of the most devastating tsunamis in world history. The tsunami caused damage to most of the Asian and other countries bordering the Indian Ocean. After a decade, reconstruction has been completed with different levels of tsunami countermeasures in most areas; however, some land use planning using probabilistic tsunami hazard maps and vulnerabilities should be addressed to prepare for future tsunamis. Examples of early-stage reconstruction are herein provided alongside a summary of some of the major tsunamis that have occurred since 2004, revealing the tsunami countermeasures established during the reconstruction period. Our primary objective is to report on and discuss the vulnerabilities found during our field visits to the tsunami-affected countries-namely, Indonesia, Sri Lanka, Thailand and the Maldives. For each country, future challenges based on current tsunami countermeasures, such as land use planning, warning systems, evacuation facilities, disaster education and disaster monuments are explained. The problem of traffic jams during tsunami evacuations, especially in well-known tourist areas, was found to be the most common problem faced by all of the countries. The readiness of tsunami warning systems differed across the countries studied. These systems are generally sufficient on a national level, but local hazards require greater study. Disaster reduction education that would help to maintain high tsunami awareness is well established in most countries. Some geological evidence is well preserved even after a decade. Conversely, the maintenance of monuments to the 2004 tsunami appears to be a serious problem. Finally, the reconstruction progress was evaluated based on the experiences of disaster reconstruction in Japan. All vulnerabilities discussed here should be addressed to create longterm, disaster-resilient communities.
\end{abstract}

Key words: 2004 Indian Ocean tsunami, reconstruction, disaster preparedness, disaster risk reduction.

1 International Research Institute of Disaster Science, Tohoku University, Sendai, Japan. E-mail: suppasri@irides.tohoku.ac.jp

2 The Ministry of Marine Affairs and Fisheries, Jakarta, Indonesia.

3 Lanka Hydraulic Institute Ltd, Moratuwa, Sri Lanka.

4 Maldives Energy and Environmental Company, Male, Maldives.

5 Faculty of Mathematics and Natural Sciences, Syiah Kuala University, Banda Aceh, Indonesia.

\section{Introduction}

The 2004 Indian Ocean tsunami remains the deadliest tsunami in recorded history. The earthquake, which had a magnitude $M_{\mathrm{w}} 9.3$ and a rupture length of approximately $1200 \mathrm{~km}$ (STEIN and OKAL 2005, 2007), triggered a tsunami that reached $30 \mathrm{~m}$ in height (SynOLAKIS and Kong 2006) and caused at least 230,000 fatalities in 15 African (FrITZ and Borrero 2006; Weiss and BAhlburg 2006) and Asian countries, such as Indonesia, Sri Lanka, Thailand, the Maldives (Borrero et al. 2006; JAFFE et al. 2006; GoFf et al. 2006; RuANGrassameE et al. 2006; FritZ et al. 2006; ОкаL et al. 2006a), and other island countries in the Indian Ocean (ОкаL et al. 2006b, c). Lessons were learned and good practices were developed as a result of this event. Far-field tsunami hazards from other possible sources were also studied after the 2004 event, focusing on various countries (Løvholt et al. 2006; BurbidGe et al. 2008; LatieF et al. 2008; OKal and SynolaKis 2008; SuPPaSRi et al. $2012 \mathrm{a}$, b). In addition, disaster risk-reduction elements, such as tsunami early warning systems, evacuation buildings, tsunami memorials, tsunami museums and disaster education programs, were developed in this region. This paper presents a summary of the progress made with regard to disaster preparedness over the last 10 years in Indonesia, the Maldives, Sri Lanka and Thailand based on studies, observations and our collaborative activities with government and international counterparts in Japan. This is somehow representative of efforts made by other nations, including the US, Germany, France, Australia, New Zealand and Chile. The main objectives are as follows: (1) to report on the 
reconstruction and vulnerabilities after 10 years, (2) to evaluate the present tsunami warning systems and emergency response measures and (3) to discuss disaster awareness in terms of education, memorials and the geological evidence that remains and conveys the risk of tsunami impacts. In considering the first objective, we present a summary of the reconstruction of housing and vital infrastructure and the restoration of businesses, land use and education in the affected countries during the initial years after the disaster. To address the second objective, large earthquakes that have generated ocean-wide tsunami warnings and have impacted the region are evaluated. Finally, to address the third objective, we assess the progress made with regard to disaster preparedness and the future challenges faced in these areas.

\section{Early Stage Reconstruction After the 2004 Indian Ocean Tsunami}

This section describes several examples of the early-stage reconstruction conducted during the first few years after the 2004 tsunami, including housing, lifeline and business restoration, land use management, disaster reduction education and the internal conflicts.

\subsection{Housing Reconstruction}

Sri Lanka is used as an example here. The tsunami hit the Eastern, Southern and Western coasts of Sri Lanka $2-3 \mathrm{~h}$ after the earthquake, with maximum measured run-up heights from several meters to $10 \mathrm{~m}$ or more (GofF et al. 2006). The tsunami killed more than 31,000 people and destroyed 80,000 houses, displacing more than 500,000 people (KHAZAI et al. 2006). Housing reconstruction was studied by MuraO and NaKazato (2010), who used data on more than 56,000 transitional houses and 28,000 permanent houses in the tsunami-damaged areas of Sri Lanka. They computed the recovery ratio-the ratio of the number of buildings constructed per month-to the total number of completed buildings as of February 2006, 15 months after the tsunami. Approximately $50 \%$ of the reconstruction was completed after 5 months for the transitional houses and after
8 months for the permanent houses. The transitional houses were constructed mainly during the first period after the tsunami, whereas the construction of permanent houses began after careful evaluation by the government and stakeholders. In Sri Lanka, no-construction zones existed in areas that underwent the rehabilitation process. The reconstruction and the resettlement has been performed considering the initial no-construction zones (FRANCO et al. 2013) declared as $100 \mathrm{~m}$ in the South and West, $200 \mathrm{~m}$ in the East, and $500 \mathrm{~m}$ in the North. However, these initial no-construction zones obtained opposition from the local community as they created severe constraints on their daily lives and livelihoods, and as a result the buffer zones were revised to $25-50 \mathrm{~m}$ in the Southern Districts and a minimum of $50 \mathrm{~m}$ on the Eastern coast. Although the 200, 500 and 25-50 m no-construction zones are not arbitrary, broad nobuild zones still exist and affect people's livelihoods.

\subsection{Lifeline Infrastructure Reconstruction}

A comparative study of lifeline reconstruction between the cases of Okushiri Island, Japan, after the 1993 tsunami and Nam Khem village in Phang Nga province of Thailand was performed by TAKADA et al. (2010). They reported that the water and power supply reconstruction in Nam Khem village took approximately 1 and 3 months, respectively, whereas the full recovery of lifelines took 5 years on Okushiri Island. This difference was due to the preference of the local residents of Nam Khem village to rebuild in the same place where they had lived before the tsunami. Therefore, the local residents were able to move into their new permanent houses directly from the evacuation shelter. Conversely, on Okushiri Island, the local residents worked for many years together with the local government to design a new, resilient town to mitigate future disasters.

\subsection{Business Restoration}

A survey of business restoration was carried out in Galle, Sri Lanka, in 2005 (Kuwata and TAKadA 2010). Galle, the capital city of Southern Sri Lanka and known as the location where the tsunami swept away a train with almost 2000 passengers, is located 
on the south tip of Sri Lanka where the tsunami inundation depth measured more than $5 \mathrm{~m}$ (GoFf et al. 2006). In this study, business restoration was defined by the amount of sales of a product after the tsunami compared to the amount of sales of the same product before the tsunami. The data were obtained through interviews with shop owners. Financial services and lifelines were the two types of businesses that were restored most quickly. These businesses were fully restored after 2 months because both were considered important for the overall reconstruction. Moreover, agricultural restoration took approximately 6 months. Although the farmers may be situated far away from the sea, the agricultural sector took longer time to completely restore as it was necessary to first remove contamination of the soil due to salinity (Kuwata 2011). Tourism, manufacturing and both wholesale and retail businesses were slowly restored; approximately $50 \%$ were restored 6 months after the tsunami. One of the reasons for this was the reduction in visiting international tourists. Fisheries suffered the most; less than $40 \%$ were restored 1 year after the event. Reasons for this include the damage incurred by fishing boats and the rumors of incurring health risks from eating seafood from the area.

\subsection{Land Use Management}

An example of land use management as an important adaptive strategy for tsunami resilience in the Maldives was presented by RIYAZ and PARK (2010). The Maldives is a country that is extremely vulnerable to many types of hazard, i.e., storm surges, torrential monsoon rain, sea level rise, tidal waves and tsunamis. Unlike other countries in the Indian Ocean, the average height of Maldivian islands is $1.5 \mathrm{~m}$ above Mean Sea Level which exacerbates the challenges associated with the tsunami evacuation process (Ministry of Environment, Energy and Water 2007). Therefore, the "Safer Island Concept" (FrITZ et al. 2006) was proposed as follows: (1) establish environmental protection zones (EPZs): high-level sand bunds or embankments to protect the islands from a high rise in sea level, (2) create lower drainage areas on the landward side between the ring road and the EPZ for proper water drainage and (3) build elevated ground or high-rise buildings for vertical evacuation. Vertical evacuation sites can act as a good solution to the problem, but these sites must be built to withstand the great impact, which includes floating debris. The government of the Maldives decided to pursue this concept on ten islands as a long-term goal. However, only two islands have presently been developed as "safer islands". In addition, the two islands developed as "safer island" do not strictly follow the concept outlined above.

\subsection{Disaster Reduction Education}

Education is important in addition to reconstruction. Examples of new efforts in disaster reduction education in Thailand, at the government level, and Indonesia, at the local level, are discussed in this section. SIRIPONG (2010) reported that, in Thailand, three government agencies provide disaster reduction education: (1) the Ministry of Education, for schools and universities, (2) the Department of Disaster Prevention and Mitigation, for operational and rehabilitative academies, and (3) the National Disaster Warning Center. The role of each agency and their collaboration with international organizations are explained in the study. Gото et al. (2010) introduced an example of educational materials and methods at the local level: a collaborative workshop between Japanese and Indonesian universities. Visual educational aids, such as computer graphic of tsunami, and exercises, such as evacuation drills and the preparation of evacuation maps, were judged to be effective educational tools. YASUDA et al. (2014) present similar activities in the 2004 tsunami-affected countries (Indonesia and Thailand), the 2011 tsunamiaffected area in Japan, and the 2013 Typhoon Haiyan-affected area in the Philippines and Hawaii. They found that after the activity, for example, $20 \%$ of the students changed their mind from agreeing to totally agreeing to tell their parents what they have learned in class.

\subsection{Internal Conflicts}

There are some examples of internal conflicts associated with the early-stage reconstruction of this tsunami disaster as both Indonesia and Sri Lanka had 
been affected by civil war for several decades before the tsunami (BAUMAN et al; 2007; ENIA et al. 2008; Hyndman 2009; Kunn 2009). Two of the main issues raised during the early-stage reconstruction are (1) public safety of post-tsunami buffer zone/empowerment issues among the government and rebels, and (2) distribution of aid and goods from international institutions (Hyndman 2009). However, the result of the conflicts after the tsunami is different in both countries. Banda Aceh achieved peace after an agreement in 2005 and greater access of natural resources such as oil and gas even before the tsunami. On the other hand, civil war was renewed in Sri Lanka with the loss of government power. These examples suggest the need to pay more attention to post disaster conflict zones given their potential of both positive and negative ends (ENIA 2008).

\section{Review of the Indian Ocean Tsunami Events After 2004 and Their Impacts}

This section describes the three major tsunamis triggered by earthquakes with magnitudes of approximately M 8.0 or greater and their impacts on countries bordering the Indian Ocean. These three events occurred after the 2004 Indian Ocean tsunami: the 2005 Nias earthquake, the 2007 Sumatra earthquake, the 2010 Mentawai earthquake and the 2012 Indian Ocean earthquakes, as shown in Fig. 1.

\subsection{The 2005 Nias Earthquake and Tsunami}

This earthquake occurred on 28 March 2005, 3 months after that of December 2004, with a magnitude of M 8.7 (USGS 2005). The earthquake was felt on the entire west coast of Malaysia and in high-rise buildings in Singapore and Thailand, among other countries. The ground motion reached as far as the Andaman Islands, but it was not felt on the Indian mainland (ASC 2005). The epicenter was located in a shallow water region, producing a high-intensity earthquake but a small tsunami. Based on field survey data (BoRRERo et al. 2011), the tsunami runup height was approximately $4 \mathrm{~m}$ or less at areas near the epicenter. These values are comparable to those of the 2004 tsunami at the same location. Smaller waves were detected at tide gauges in the Indian Ocean in comparison to the 2004 event shown in brackets: for example, $0.10 \mathrm{~m}(1.08 \mathrm{~m})$ in Male, the Maldives; $0.13 \mathrm{~m}(0.30 \mathrm{~m})$ in the Cocos Islands, Australia; and $0.21 \mathrm{~m}(1.50 \mathrm{~m})$ in Colombo, Sri Lanka (NOAA/ NGDC 2014). Tsunami warnings were issued by the Pacific Tsunami Warning Center to many countries in the region but were later cancelled. People in Indonesia, India, Malaysia, Sri Lanka and Thailand evacuated to safer places by moving to higher ground, whereas traffic jams occurred on the roads leading out of Banda Aceh, Indonesia, and the coastal areas of Chennai, India (ASC 2005). Fatalities were due primarily to the strong ground motion in areas near the epicenter; however, the USGS (2005) reported that at least ten people died from panic during the evacuation from the Sri Lankan coast.

\subsection{The 2007 Sumatra Earthquake and Tsunami}

Another large earthquake of magnitude M 8.5 (USGS 2007) occurred in this region on 12 September 2007, 3 years after the 2004 event. Similar to the event in 2005, the earthquake was felt in countries as far as Malaysia, Singapore and Thailand, and highrise buildings were used for evacuation (BBC 2007). In addition, tsunami warnings were issued to several countries in and around the Indian Ocean, including small islands and Indonesia, India, Malaysia, Sri Lanka and even Kenya (BBC 2007). A moderate tsunami with a runup height of approximately $4 \mathrm{~m}$ was measured in the areas near the epicenter (BoRRERO et al. 2009). Relatively smaller tsunami waves were observed at tide gauges in the Indian Ocean, including $0.40 \mathrm{~m}$ in Phuket, Thailand; $0.11 \mathrm{~m}$ in Male, the Maldives; $0.12 \mathrm{~m}$ in the Cocos Islands, Australia; and $0.30 \mathrm{~m}$ in Colombo, Sri Lanka (NOAA/NGDC 2014). Although the tsunami caused destructive damage to buildings and facilities, no one was killed due to the successful tsunami evacuation following warning messages that reached residents via TV or radio (Imamura 2008).

\subsection{The 2010 Mentawai Earthquake and Tsunami}

Although the magnitude of this earthquake (M 7.8) was smaller than the others discussed in this 


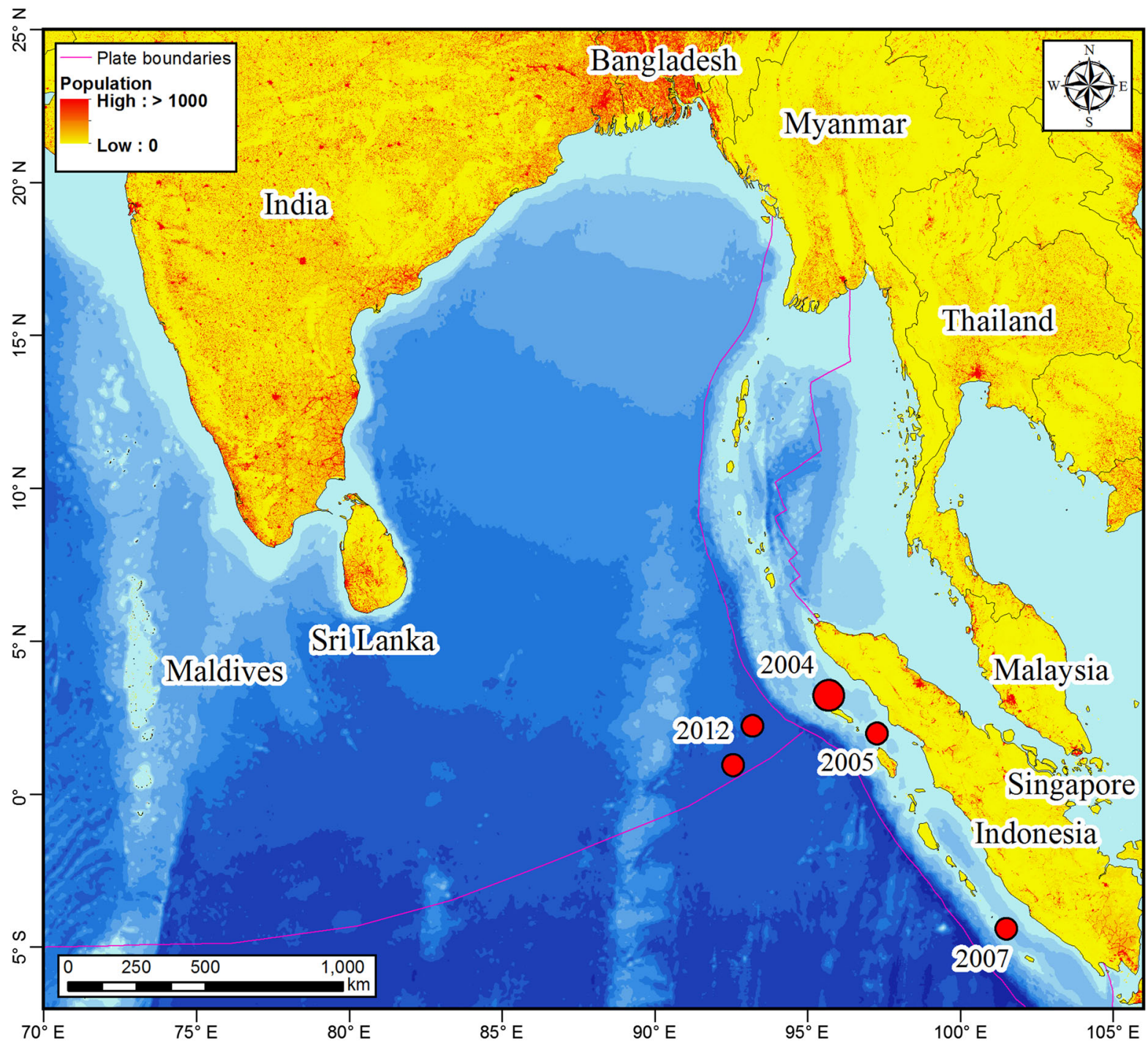

Figure 1

The locations of the major earthquakes in the Indian Ocean since 2004 and the population distribution, revealing the vulnerability of this region. (Original data from Oak Ridge National Laboratory 2006)

section, the number of casualties was the largest (as high as 509) (NOAA/NGDC 2014). In fact, this earthquake was considered a "tsunami earthquake" that generated a much larger tsunami than expected from the seismic magnitude, insofar as the observed tsunami was 4-7 m high (Tomita et al. 2011; SATAKE et al. 2013) and the maximum runup was measured as high as $16.8 \mathrm{~m}$ (HiLl et al. 2012). Issues that might have magnified the damage and impact include the following: (1) risk bias: the previous large earthquakes generated strong ground motions but did not generate significant tsunami; the slow ground motion during the 2010 earthquake thus brought a false sense of safety, and most people thought that no tsunami would follow (MuHari and Imamura 2014); (2) the earthquake occurred at night; (3) the earthquake occurred in a location where there was less awareness; and (4) there was no adequate tsunami warning 
infrastructure to warn the local people. There was no damage reported in the mainland areas where the earthquake was felt, but the tsunami damaged the remote Mentawai Islands, where the tsunami arrived as soon as 5-15 min after the earthquake in some areas. Here, there was also a problem with the tsunami warning systems. Villagers were not given early warning because some buoys had been vandalized, and the equipment had been too expensive to replace (The Telegraph 2010). However, some communities, particularly those residing in the northern part of the affected areas-which is famous for its surfing activities-were able to evacuate; the evacuation was possible not because of the warning but because of the surfers' guidance (Мікамі et al. 2014). Therefore, this event signifies the importance of education for self-evacuation, especially in such remote areas or areas where tsunamis could arrive swiftly. The 2010 tsunami was also observed in other countries, reaching heights of $0.09 \mathrm{~m}$ in Colombo, Sri Lanka; $0.11 \mathrm{~m}$ in Male, the Maldives; and $0.16 \mathrm{~m}$ in the Cocos Islands, Australia (NOAA/NGDC 2014).

\subsection{The 2012 Indian Ocean Earthquakes and Tsunami}

The last two sizable events were both outer-rise earthquakes (an unusual type of earthquake that occurs near oceanic trenches; GEIST et al. 2009) of magnitudes over M 8.0 that occurred in North Sumatra on 11 April 2012. One of the earthquakes had a magnitude of $M$ 8.6, whereas the second earthquake presented with a magnitude of $\mathrm{M} 8.2$; they were located 100 and $200 \mathrm{~km}$ southwest of the major subduction zone (USGS 2012), respectively. They were felt in areas as far away as Malaysia, Thailand, India and the Maldives, and tsunami warnings were issued for all countries bordering the Indian Ocean (Aljazeera 2012). Residents of Indonesia, Thailand, Sri Lanka and India were advised to move to high ground or to stay far away from the sea. Nevertheless, due to the strike-slip type of these earthquakes, no significant damage was reported in the countries surrounding the Indian Ocean, and the tsunami height was recorded at approximately $0.05 \mathrm{~m}$ in Phuket, Thailand; $0.08 \mathrm{~m}$ in the Cocos Islands, Australia; $0.21 \mathrm{~m}$ in Male, the
Maldives; and $1.08 \mathrm{~m}$ in the port of Meulaboh, Aceh, Indonesia (NOAA/NGDC 2014).

\subsection{Return Period of the 2004 Event-Like Earthquake}

One important issue is the recurrence of major tsunami such as the 2004 event. Information of the earthquake return period in the Indian Ocean basin can be obtained from the following studies. BURBIDGE et al. (2008) derived hazard curves representing the earthquake return period as a function of magnitude in Java, Sumatra, Nankai, Seram and South Chile. The data were mainly based on the earthquake focal mechanisms of all the earthquakes in the Global CMT catalogue for the eastern Indian Ocean region since 1976 with $M_{\mathrm{w}} \geq 7.0$ and depths less than $100 \mathrm{~km}$. Because records of seismicity are rarely long enough, they proposed their own method developed to avoid underestimating the return period due to infrequent earthquake events in the area. From their proposed hazard curve, it was estimated that a 2004 tsunami-class earthquake might occur every 1000 years.

A similar earthquake return period was shown in a study by LATIEF et al. (2008). They considered four main subduction segments as tsunamigenic sources in Aceh-Seumelue-Andaman and Nias. The analysis was conducted using the EZ-FRISK program to provide a hazard curve correlating earthquake return periods and the potential moment magnitudes while considering the seismic parameters adopted in the recurrence models. Their results indicate that the recurrence of an event comparable to the 2004 tsunami is approximately 520 years.

Another method for calculating the earthquake return period was used in an investigation of sand sheets in Phang Nga province, Thailand (JANKAEW et al. 2008). From the results of this study, it was concluded that the full-sized predecessor to the 2004 tsunami occurred about 550-700 years ago. The same survey method was conducted in Aceh province, Indonesia (Monecke et al. 2008). They concluded that the recurrence of the 2004 tsunami is about 600 years which agrees with the estimation by LATIEF et al. (2008) and JANKAEW et al. (2008). Therefore, approximately 600 years may be 
considered a suitable number for the return period of the 2004 event such as earthquake. This information is very important for disaster planning and policymaking.

\section{The Situation in Indonesia}

\subsection{Overview}

In contrast to Japan, which has a long history of tsunami disasters and has implemented countermeasures, the word "tsunami" was not commonly heard and its impacts were not well understood in Sumatra prior to the 2004 Indian Ocean tsunami, even though there were some major tsunami events prior to the 2004 event such as the 1992 Flores and the 1994 Java tsunamis. The tsunami of 2004 destroyed 120,000 homes and heavily damaged 70,000 more, destroying 3000 government buildings (including hospitals and schools) and 14 seaports. Nearly $3000 \mathrm{~km}$ of roads in this region were damaged, and 150,000 people lost their lives. Overall, the tsunami affected $800 \mathrm{~km}$ of Indonesia's coastline, with a total affected area of $413 \mathrm{~km}^{2}$ (S AMEK et al. 2004).

Because of the breadth and scale of the disaster, the Indonesian government established a special agency, called the Agency for Reconstruction and Rehabilitation in Aceh and Nias (BRR Aceh-Nias), to conduct reconstruction activities in Banda Aceh and the surrounding areas. This agency began to operate in mid-2005. With only a 4-year tenure, reconstruction activities focused on the development of housing (2005 to mid-2007), the development of public infrastructure (2005-2008), institutional and social development (2005 to mid-2009) and economic development (2005-2009). The agency's overall reconstruction expenses were 6.7 billion USD, which came from the Indonesian government (37\%), bilateral and multilateral donors (36\%), and national and international non-governmental organizations (27\%).

The redevelopment of the Aceh region was conducted with a community participatory method at the village level. For instance, a community would decide whether its area would be rebuilt using land consolidation or if it would be left as it was.
Along with these village-level reconstruction efforts, facilities and infrastructure for future tsunami mitigation were also designed at a higher level. A field visit was organized in November 2014 to observe these facilities as shown in Fig. 2. Buildings for vertical evacuation are now ready for use in Banda Aceh (Fig. 3a), and evacuation routes have been tested in national and international tsunami drills, in which all countries affected by the 2004 tsunami performed the drills. Recognizing that experiencing the enormity of a tsunami is important, the media has been employed to disseminate the tsunamirelated experiences from 2004 to future generations in various forms. A tsunami museum (Fig. 3b) was established in Banda Aceh along with 85 tsunami poles that indicate the height of the tsunami that hit the area. Other forms of memorials, such as ships (Fig. 3c), including a large diesel power plant vessel that was carried approximately $3 \mathrm{~km}$ inland, were left in place as a memorial for future generations (Fig. 3d).

\subsection{Development of Tsunami Early Warning Systems}

The development of a tsunami early warning system has been one of the major initiatives in Indonesia since the 2004 Indian Ocean tsunami. It was first developed under cooperation between the Indonesian and German governments in 2005 (MüNCH et al. 2011; PARIATMONO 2012). It was launched in 2009 and the present status is reviewed by LaUterjung et al. (2015). Since its development, the system has been tested by both near- and far-field actual tsunamis (MUHARI and IMAMURA 2014). The primary aim of an early warning system is to disseminate the information that a tsunami might occur after the occurrence of an earthquake; the Indonesian tsunami early warning system (InaTEWS) is able to issue a tsunami warning within 5 min after an earthquake (PARIATMONO 2012).

Tsunami buoys are not yet integrated in the overall warning system. The buoys are managed by an institution, which is separate from BMKG (Badan Meteorology, Klimatologi dan Geofisika, or the Meteorology, Climatology and Geophysics Agency). The challenge this system faces is not only when the warning is issued but also when the warning should 


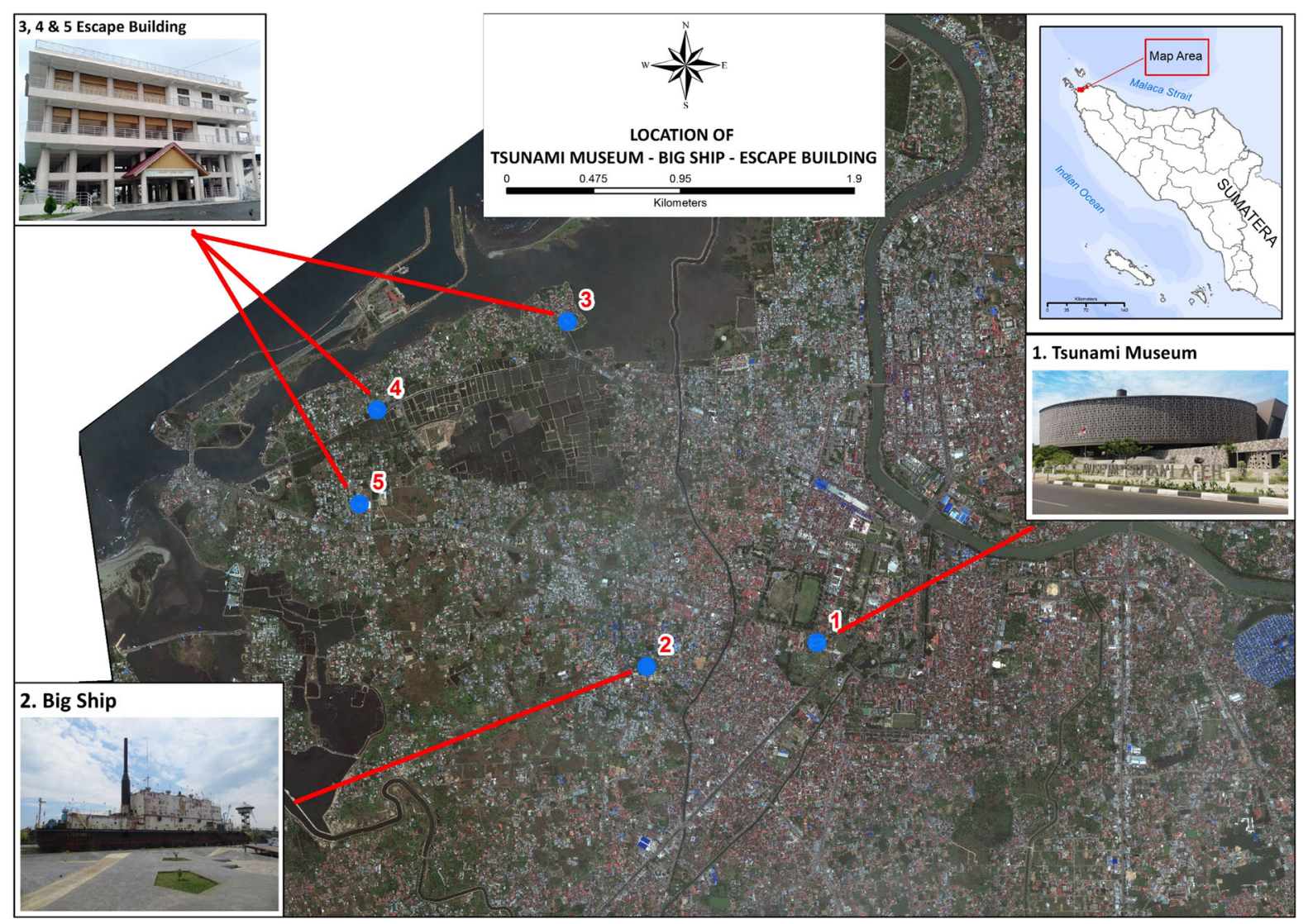

Figure 2

Locations in Banda Aceh, Indonesia mentioned in this study

be cancelled. During the 2010 Mentawai earthquake, the warning was terminated $51 \mathrm{~min}$ after the earthquake, although the tsunami was still occurring up to $2 \mathrm{~h}$ later, particularly in the small bays in the remote Mentawai Islands (Muhari and Imamura 2014). The decision to terminate the warning was made after considering real-time data from the nearest tide gauges, which indicated the tsunami height was only as high as $0.22 \mathrm{~m}$ (in Enggano) prior to the warning's termination (BMKG 2010). However, those tide gauges were located approximately $300 \mathrm{~km}$ away from the source (Fig. 5). Near the source, in the southern part of the Mentawai Islands, located only $50 \mathrm{~km}$ from the rupture area, the tsunami height was much higher, ranging from $2 \mathrm{~m}$ to a maximum of $17 \mathrm{~m}$, as observed on the small Sibigau Island located near South Pagai Island (Hill et al. 2012; SATAKE et al. 2013).
Moreover, during the 2011 Japan tsunami, the tsunami warning in the east Indonesian region was terminated just after the first wave arrived. However, the largest wave came $1 \mathrm{~h}$ later and caused the death of a local who had returned to the lowland after receiving notice that the warning had been terminated (Diposaptono et al. 2013). The lack of real-time measurement data for continuously updating the warning level or for indicating whether a tsunami has been generated is one of the issues that needs to be resolved. In addition, disseminating warnings in remote areas, such as small islands, is another challenge for future improvements to the system.

From the perspective of warning dissemination, even though the National Tsunami Warning Center (BMKG) had successfully issued a warning within 5 min after the earthquake, the local sirens did not sound because they relied on the affected city's 


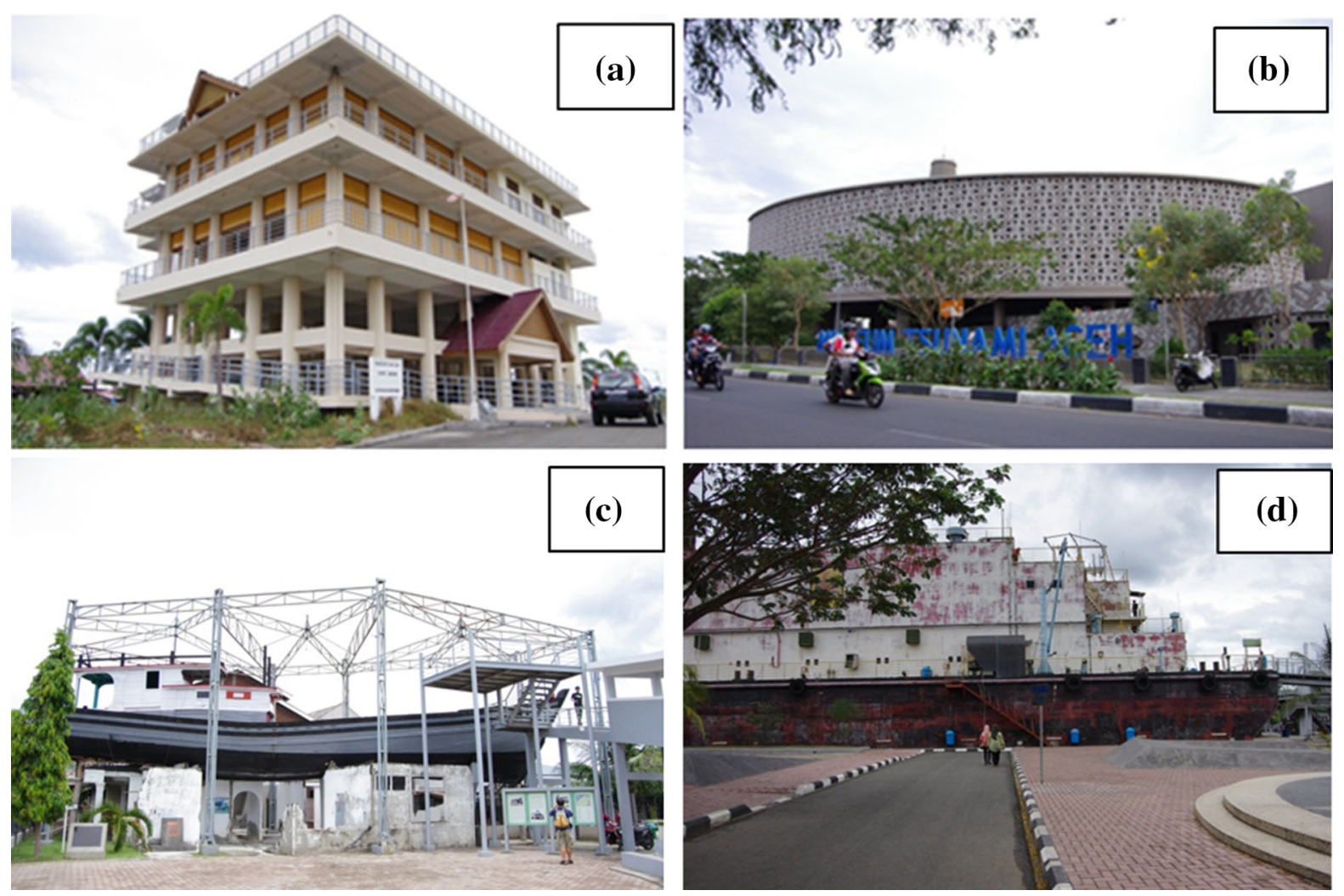

Figure 3

a One of the four vertical evacuation buildings in Banda Aceh, $\mathbf{b}$ the tsunami museum in Banda Aceh, with an evacuation sign indicating the entrance, $\mathbf{c}$ the memorial site of a stranded ship and $\mathbf{d}$ the 2600 -ton floating power plant that was swept inland by the tsunami

electricity, which was usually automatically shut off during the earthquake. Manual activation of the sirens was difficult because the officer in charge of them also evacuated after the earthquake. Such a practical problem should be addressed to ensure safe evacuation in the future.

\subsection{Tsunami Evacuation Condition}

The other issue is the human response to warnings. The 2012 Indian Ocean earthquake was likely the best opportunity to test the preparedness of the people of Banda Aceh against tsunamis. The magnitude M 8.6 earthquake triggered a massive evacuation even though the tsunami sirens in Banda Aceh did not sound until $70 \mathrm{~min}$ after the initial shock. Most of the people evacuated using motorcycles to quickly escape the lowland area. Although vertical evacuation buildings were available in the lowland, most of the residents did not believe that the structures could withstand the earthquake and tsunami. The majority of people in Banda Aceh thought that horizontal evacuation was the best choice. As a result, massive traffic jams were observed along the main road of Banda Aceh City during the evacuation. According to a survey conducted after the event (Gото et al. 2012c) among 161 people who evacuated (of the total 220 respondents), 153 were trapped in the traffic jam during the evacuation. Respondents did not believe that the vertical evacuation structures could increase their chances of successfully evacuating given the limited time before the tsunami would arrive. The lack of community participation in determining the location and design of the vertical evacuation structures is believed to be one of the reasons why, even now, people do not trust that vertical evacuation structures 
can save their lives. In addition, the lack of interest in these structures has led to poor maintenance of the facilities (Fig. 4), which are rarely used, even for social activities, by the residents who live near the buildings.

Banda Aceh city has made several plans to reduce the problem of traffic jams during emergency situations to facilitate evacuation of future disaster. Tsunami evacuation simulation was conducted (Gото et al. 2012b) and some plans have been realized such as widening existing roads which are to act as escape roads, and also making emergency crossings on twoway main roads. This emergency crossing will be used in emergency situations to shorten U-turns or to cut the road block so that traffic jams can be avoided or reduced. Another plan to be implemented in 2015 is to make a flyover on roads with heavy traffic and to also make an underpass on the designated road that has been identified by the city government. With support from the National Agency for Disaster Management (BNPB) Banda Aceh city has made a tsunami evacuation road map. This tsunami evacuation road map should be publicized to Banda Aceh city residents to facilitate proper evacuation for future disaster mitigation.

\subsection{Design of Evacuation Buildings}

An evacuation building in Banda Aceh has been designed with four stories and an overall height of $18 \mathrm{~m}$, and incorporates 54 columns each having a diameter of $70 \mathrm{~cm}$. The roof includes a helipad for helicopter landings. In a large-scale tsunami evacuation drill which was held on 2 November 2008, a helicopter was landed there smoothly. The second floor has a height of approximately $10 \mathrm{~m}$, as indicated by the 26 December 2004 tsunami wave height at the location of the building. The first floor is left open with no partitions or hollow structures, following the concept of the mosque. The aim is to avoid the wave force of future tsunamis. The building can accommodate the evacuation of 500 people and is designed to withstand earthquakes with a moment magnitude of 10 on the Richter scale. The stairs leading to the upper floor is made of two parts. One main staircase has a width of approximately $2 \mathrm{~m}$ and another one has a width of $1 \mathrm{~m}$ with the slope designed to accommodate the use of wheel chairs in emergency situations. The building is also equipped with facilities for emergency situations. The building serves as a community center that is surrounded by villagers who are alert and ready to mitigate the effects of disasters.

\section{The Situation in Sri Lanka}

The 2004 Indian Ocean tsunami is remembered as the most devastating catastrophe in Sri Lanka, having caused 35,000 fatalities on two-thirds of the coastal belt, across 13 coastal districts (ADB 2005). The waves penetrated approximately $500 \mathrm{~m}$ inland, on average, to a maximum of $2 \mathrm{~km}$ on the east coast and
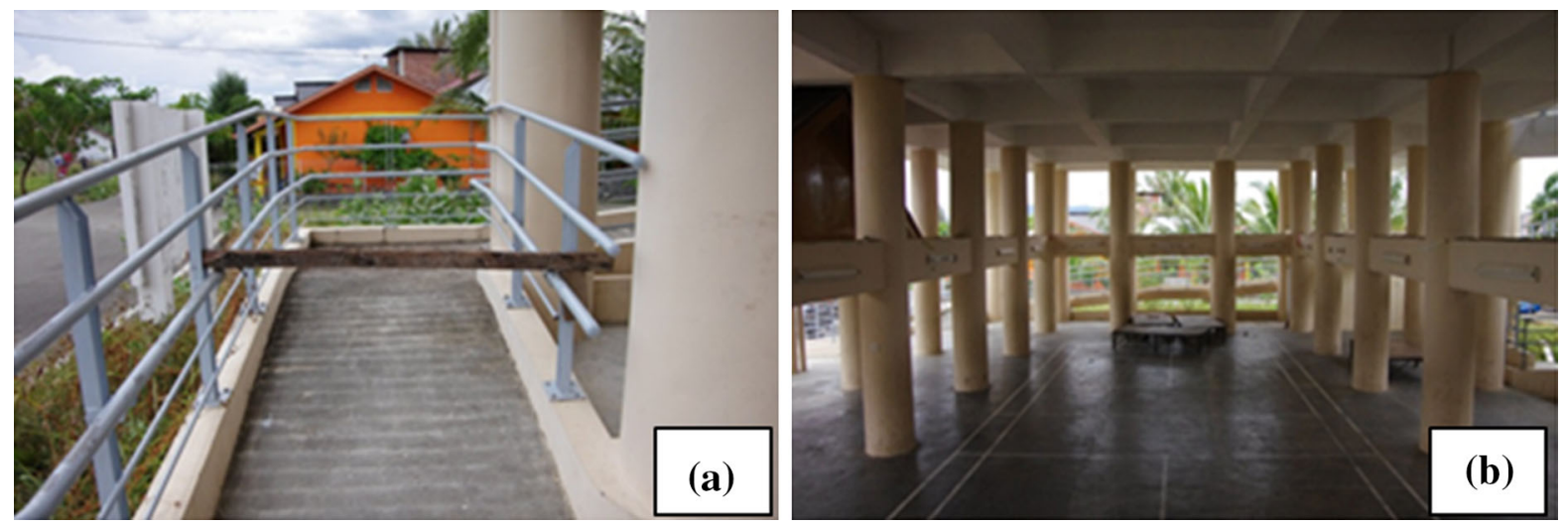

Figure 4

a A wooden bar blocking the entrance for disabled persons to the evacuation building and $\mathbf{b}$ the first floor of the evacuation building 
with a maximum tsunami runup recorded on the southern coast over $10 \mathrm{~m}$ in Yala (Liu et al. 2005) and Hambantota (WiJetunge 2009). The damage in Sri Lanka was particularly severe along the coast from east to south. The damage was dramatically more significant because no tsunami early warning system existed in Sri Lanka at the time due to the country being located very far from active faults.

Since the 2004 event, several individuals and national and international organizations have supported the recovery of the damaged areas on a shortterm and long-term basis. Providing food, clothing and temporary shelter to displaced populations comprised some of the immediate actions taken by authorities. Resettlement and reconstruction activities supervised by the Ministry of Relief, Rehabilitation and Reconstruction commenced after the completion of the relief activities (ADB 2005). Reconstruction activities were further enhanced by short-term and long-term plans that led to the establishment of a powerful body called the Disaster Management Center (DMC) in 2005. However, there have been many challenges regarding the policy to create urban development strong enough to withstand future disasters. The 2004 tsunami itself created the unforgettable example of a lack of awareness of tsunami events leading to devastating damage in Sri Lanka even though it was a far-field tsunami. This occurred, in part, because there are still very few tsunami experts in Sri Lanka; consequently, hazard and risk evaluations have been insufficient. Our group monitored the recovery process in Sri Lanka from 2010 to 2013 with the cooperation of the Japan International Cooperation Agency and the Miyagi Prefecture in Japan. Here, we briefly summarize our work and discuss the current problems related to the recovery process and to future tsunami countermeasures in Sri Lanka.

\subsection{The Current Conditions of Severely Damaged Areas}

Galle City was severely damaged by the 2004 Indian Ocean tsunami (Fig. 5). The tsunami runup height in this city was estimated at 4-5 m (LiU et al. 2005; WiJetunge 2009). The placement of tsunami signs, the designation of hazard zones and disaster prevention education activities have been conducted

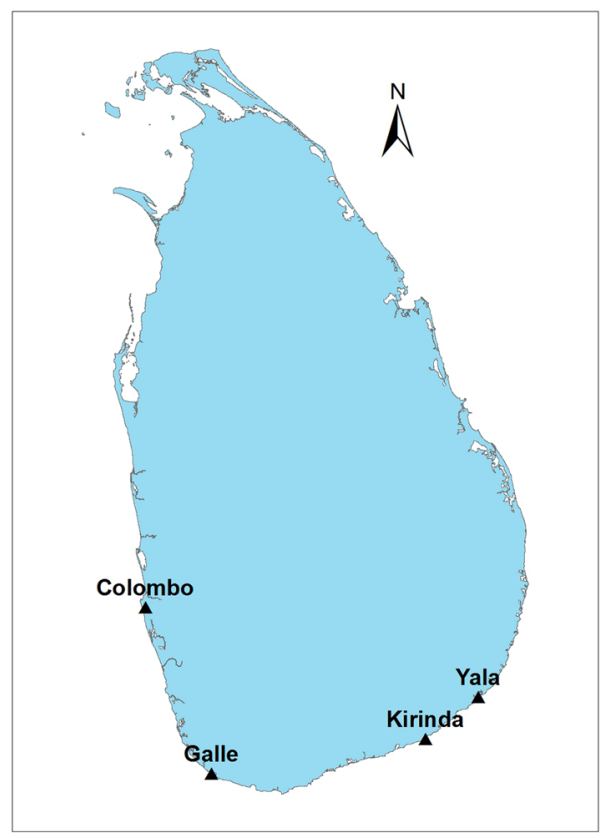

Figure 5

Locations of coastal cities in Sri Lanka mentioned in this study

by city authorities, universities and schools. A group from the Faculty of Engineering at the University of Ruhuna in Sri Lanka prepared a tsunami hazard map and evacuation plan for Galle City following the guidelines that were being used in Japan (Coastal Development Institute of Technology 2004), and this was one of the initial activities that led to increasing people's tsunami awareness (WIJAYARATNA et al. 2006). However, it is difficult to continue disasterprevention activities with a limited budget and changing levels of awareness of tsunamis in the local population. This problem is likely to be widespread among tsunami-affected countries. Consequently, it is important to determine how to continue disasterprevention activities over the long term. For example, there is a Tsunami Photo Museum in Telwatta containing thousands of photographs taken during and after the tsunami as well as paintings by children. However, the museum is operated by the private sector, so it is important to determine how to continue to support such a museum. According to the DMC, the establishment of a disaster information system has been completed. However, the hazard map for various types of natural disasters and the action agenda for disaster prevention require improvement. 
Hambantota and Yala are other locations on the southern coast that were severely affected by the Indian Ocean tsunami (Liv et al. 2005; Goff et al. 2006). Being mostly flatland, Hambantota City was affected by the tsunami, and a lack of awareness by its people increased the damage it experienced. During our 2012 visit to Sri Lanka, we were able to visit Yala, where many casualties were reported, including 15 foreigners. A safari tour guide from Yala who was a witness to the Indian Ocean tsunami stated that the tsunami flow that came through the lower lands was strong enough to kill the people who were on the safari tour even though the Yala area is covered by sand dunes. He further emphasized that most of the animals in the Yala wild park were safe and that people died because of their lack of awareness of the event. In addition to localized reconstructions and developments, the DMC was able to create a well-planned early warning system for disasters, including 74 early warning towers that cover the entire coastal belt of Sri Lanka; the aim of these towers is to issue tsunami and storm surge warnings.

\subsection{The Recovery of Harbor Functions}

The damage the Indian Ocean tsunami caused to coastal infrastructure, ecosystems and the fishery sector was significant. Nearly $80 \%$ of fishing boats and ten out of the twelve fishery harbors were badly damaged (CH2MHill 2006). Hikkaduwa, Mirissa, Galle, Puranawella, Hambantota and Kirinda are harbors that were considered highly damaged due to the tsunami. The Kirinda fishery harbor is a good example of engineering projects that mitigate natural phenomena. After its initial construction, the harbor faced a serious problem in 1992: sand accumulation blocked the harbor entrance. Some civil engineering projects, such as dredging and the construction of new breakwaters, were introduced to solve the problem, but the problem continued until before the 2004 tsunami occurred (Fig. 6). The Kirinda fishery harbor was severely affected by the 2004 Indian Ocean tsunami in terms of both coastal structures and coastal morphology (e.g., Goto et al. 2011; RANASINGHE et al. 2013). During the tsunami, an approximately 8-m-high tsunami flood was recorded, and a large dredging ship called the Weligowwa was cast ashore. Because of the sand blockage, bathymetric change was being measured in detail at regular intervals. The last measurement before the tsunami was taken in November 2004. Post-tsunami bathymetry was measured from February to March 2005. According to Goto et al. (2011) and Ranasinghe et al. (2013), the first runup tsunami wave transported large amounts of offshore, sea bottom sediment and deposited it in a layer up to $4 \mathrm{~m}$ thick along the shoreface slope. Bathymetry values returned to normal by November 2005, approximately 1 year after the tsunami. After the tsunami, sand accumulation began again, and sand blockage had re-occurred by 2006 . Because the harbor was an important facility for fishermen, dredging work has been conducted such that, as of 2013, the harbor is in use.

In the case of Kirinda, the tsunami's impact on bathymetry was limited, and it recovered very quickly. However, several studies have reported that coastal geomorphology has not fully recovered from the 2011 Tohoku-oki tsunami (UDO et al. 2013). It is very important that we understand what determines whether coastal geomorphology recovers.

\subsection{Scientific and Technological Support from Japan}

In this project, the Japan International Cooperation Agency (JICA) led a collaboration with the Miyagi prefectural government and Tohoku University. The project was implemented for 3 years in 2009, 2010 and 2012. To expand the understanding of city planning in preparation for future disasters in Sri Lanka, Japanese knowledge of disaster-prevention-specific activities in the region was taught to trainees from Sri Lanka. The goals were the comprehensive support and practice of science and technology, the practice of disaster prevention, enlightenment and education. During their training in Japan, trainees learned basic disaster prevention, disaster history and the primary countermeasures and current challenges in both countries. The trainees are expected to contribute to disaster prevention and mitigation activities in Sri Lanka. In addition, education on earthquake and tsunami disaster prevention assistance in Sri Lanka was provided through seminars and workshops, the presentation and sharing of information, the exchange of ideas and the presentation of challenges. A tsunami deposit site visit to assess the risk of low frequency hazards will also be required in the future. In 

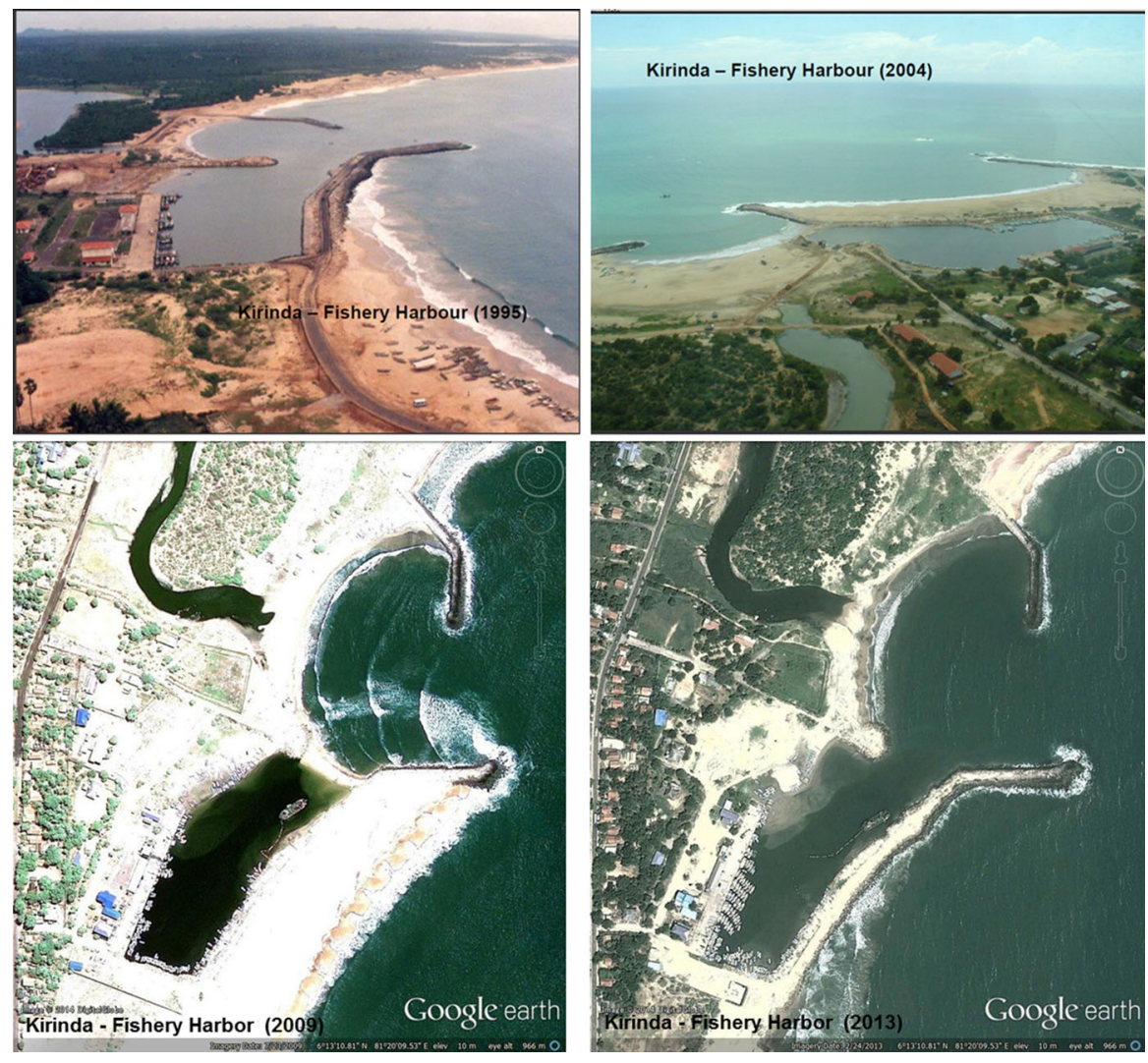

Figure 6

Bathymetric changes in the Kirinda fishery harbor in 1995, 2004, 2009 and 2013. [Image source: Lanka Hydraulic Institute Ltd (LHI) and Google earth]

addition, disaster prevention education, awarenessraising activities and community-based disaster management activities in schools and the education community, based on the Participatory Technology Assessment (PTA), were organized with local professionals. Some examples of our activities, such as a field survey of reconstruction conditions and disaster risk reduction activities are shown in Fig. 7.

\subsection{Problems with Preserving Monuments}

Unlike Indonesia and Thailand, Sri Lanka does not have a damaged structure that has been preserved as a tsunami monument. One possible monument is a train named "the queen of the sea" that was hit by the 2004 tsunami with more than 1700 passengers aboard; they became casualties due to their belief that the train would be strong enough to withstand the tsunami. This became the deadliest train disaster in recorded history. Nevertheless, this train might be too emotionally difficult for the local people to preserve as a monument. This example demonstrates the importance of disaster risk education for local people. Among the tsunami memorials that were constructed, the memorial at Peraliya in the Galle district is still in good condition and has become an attraction for tourists as well. This memorial was constructed in remembrance of the people who died in the train accident. The remaining cars of the damaged train had been kept in Peraliya but were then moved to Hikkaduwa and kept there for some time. The train was repaired and put into service, and it ran the same trip on 26 December 2008 as a memorial to the people who lost their lives. In Yala, a resort hotel and most of the vegetation were severely damaged by the tsunami (GoFf et al. 2006). After this disaster, the remnants of the bungalow were preserved, and a tsunami monument was constructed in 2005. 

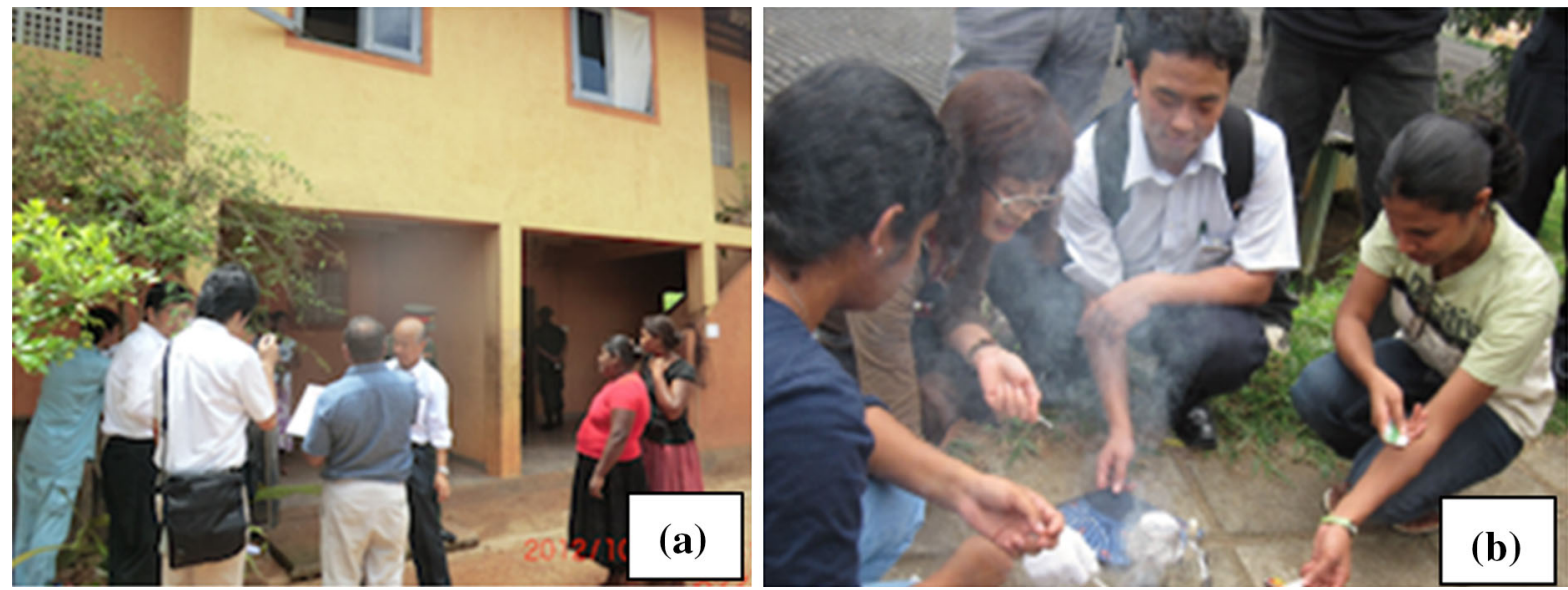

Figure 7

Interviews on disaster response and recovery conditions in Galle City and practicing survival (making rice using cans)
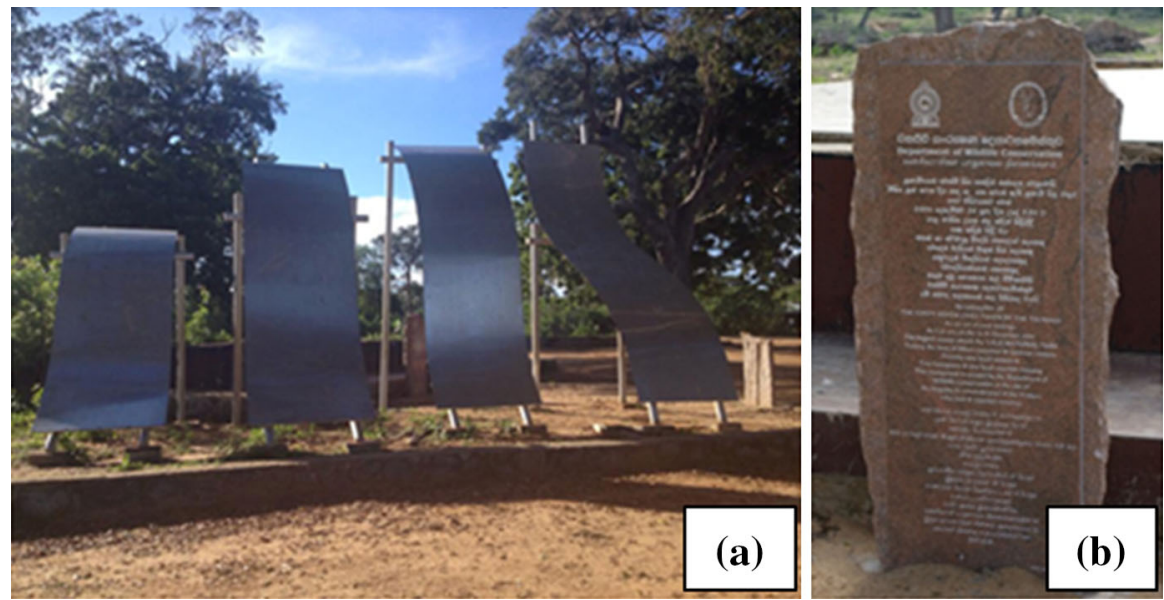

Figure 8

a A steel monument and $\mathbf{b}$ a tsunami memorial in 2005 at the Yala safari bungalow

However, as seen in Fig. 8, part of the painted writing on the monument disappeared in 2012, and it is difficult to read the text. Although it is very important to memorialize the tsunami disaster by visiting the monument, its preservation is even more important.

\section{The Situation in Thailand}

\subsection{General Observations and Future Challenges in Each Location}

A significant change in Thailand after the 2004 tsunami was the establishment of the National
Disaster Warning Center (NDWC). The NDWC obtains disaster observation data from the Thai Meteorological Department (TMD) and other international organizations and acts as the center for disaster warning in Thailand. Using this system, a tsunami warning can be issued in Thailand within 5 min after an earthquake occurs. In the six provinces that were damaged by the 2004 tsunami, there are also many examples of change, such as the preparation of tsunami hazard maps and tsunami signs and the construction of tsunami evacuation buildings. Field visits were organized in 2009 and 2013 in areas shown in Fig. 9 in collaboration with the TMD, the NDWC, the Department of Disaster Prevention and Mitigation 

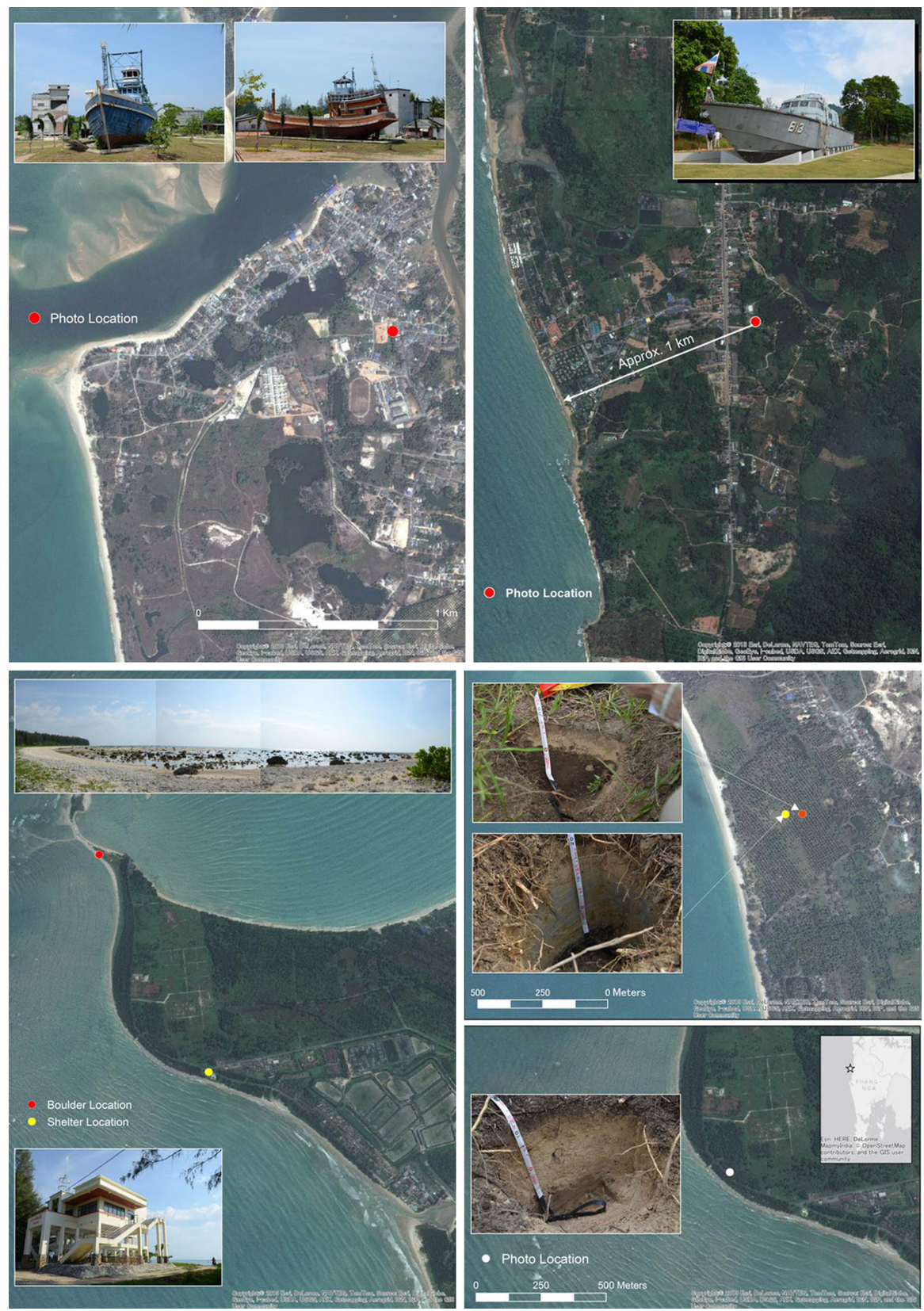

Figure 9

Locations in Phang Nga and Phuket, Thailand mentioned in this study

(DDPM) and the Regional Integrated Multi-Hazard Early Warning System for Africa and Asia (RIMES).

\subsubsection{Nam Khem Village, Phang Nga Province}

Nam Khem was one of the worst-hit areas in Thailand, where more than a thousand lives were lost as a result of flooding by a 10 -m-high tsunami wave. Most villagers were fishermen or worked in aquaculture and sightseeing. A tsunami museum and memorial were constructed near the coast, containing pictures, damage information and a list of the victims. Another tsunami memorial was made out of two large fishery boats that were transported inland by the 
tsunami, killing people and destroying houses. The population in Nam Khem village has since decreased, and the tsunami evacuation plan has been very much improved. A number of activities such as tsunami evacuation drills, reconstruction forums, and disasterrelated lectures are being conducted here, and residents are well-prepared and highly aware compared to other areas. They have their own tsunami evacuation drills and emergency plans. A sea observation team will check on the receding wave when they receive a warning. This procedure is risky and dangerous because it is not necessarily the case that a tsunami will be preceded by drawdown (SUPPASRI 2010). Education regarding to the correct basic understanding of tsunamis is still needed. A patrol team will monitor residents' property. A traffic team will implement their own rules during evacuation, having pedestrians keep left and vehicles keep right. A rescue team will check every house for remaining and possibly disabled residents. A nursing team will provide first aid. The school was moved further from the sea and to higher ground as a result of previous experience. The evacuation route for vehicles is the main road (a 2-lane road). Two types of evacuation drills are conducted, and the residents understand the problems that occur when they have to evacuate in the rain or during nighttime. As a result, their evacuation process in response to the tsunami event on 11 April 2012 was a complete success, without any problems or traffic jams. Nam Khem serves as a good example of a tsunami disaster-resilient community. In 2013, the tsunami memorial park looks similar to what was observed in 2009; however, the two fishing boat memorials (Fig. 10a) have been seriously deteriorated by corrosion due to a lack of maintenance. In addition, tsunami-related signs, such as hazard maps, tsunami height indicators and evacuation direction signs, have faded due to sunlight and other weathering processes (Fig. 10b).

\subsubsection{Pakarang Cape, Phang Nga Province}

The tsunami evacuation building in Pakarang Cape (Fig. 11a) is adjacent to the beach, in compliance with the safe zone distance of more than $1 \mathrm{~km}$, and there is no greenbelt to dissipate tsunami energy.
Construction began for the evacuation shelter in March 2009 and was completed in November 2009. There is a sign there that indicates the 2004 tsunami level of $5 \mathrm{~m}$, but the actual height of the sign is approximately $1 \mathrm{~m}$. In this area, local residents find a height of $5 \mathrm{~m}$ difficult to imagine (SUPPASRI 2010). This may lead to an underestimation of the tsunami hazard. Therefore, the height of the sign should be set equal to the height of the tsunami. A detailed study of tsunami evacuation simulation in this area, including the mentioned evacuation building, can be seen from a study by MAs et al. (2015-the same issue).

\subsubsection{Khao Lak Area, Phang Nga Province}

Khao Lak is the most popular tourist area in the Phang Nga province, where a large number of nonThai tourists were killed by the tsunami. Many hotels and resorts were also destroyed by the tsunami but had been fully reconstructed a few years after the tsunami. When the tsunami occurred, the water police patrol boat T.813 was on its way to secure one of the royal families and was swept inland across the main road, which is located approximately $2 \mathrm{~km}$ from the sea. Some of the boat's crew, including the captain, survived. The boat is now preserved as a tsunami memorial similar to those in Nam Khem village. Tsunami evacuation signs in both Thai and English were erected in many places in Khao Lak to maintain tsunami awareness. Figure 12a shows the undeveloped area containing the boat memorial with a wooden bridge crossing the river in 2009. By 2013 (Fig. 12b), the bridge structure had become concrete, and the area near the boat had been developed and now contains a memorial park, exhibition hall, travel center and other activity spaces.

\subsubsection{Patong Beach, Phuket Province}

Patong Beach is one of the most popular tourist areas in Phuket and contains many hotels, shops and restaurants. The tsunami in 2004 was not as high there as in Phang Nga. Therefore, only the first floors of buildings were damaged, and the tsunami only reached approximately $300 \mathrm{~m}$ inland. There are also a large number of tsunami signs in Patong. Large 

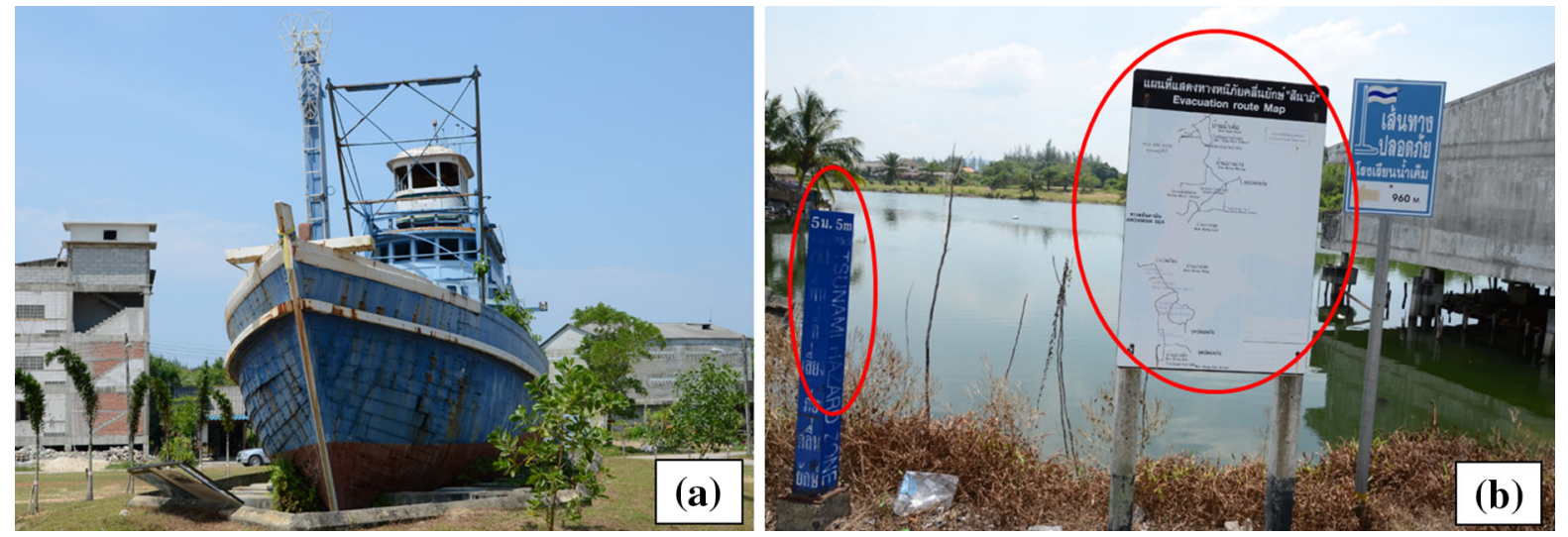

Figure 10

a Corrosion of a memorial fishing boat and b poor maintenance of tsunami-related signs in Nam Khem village
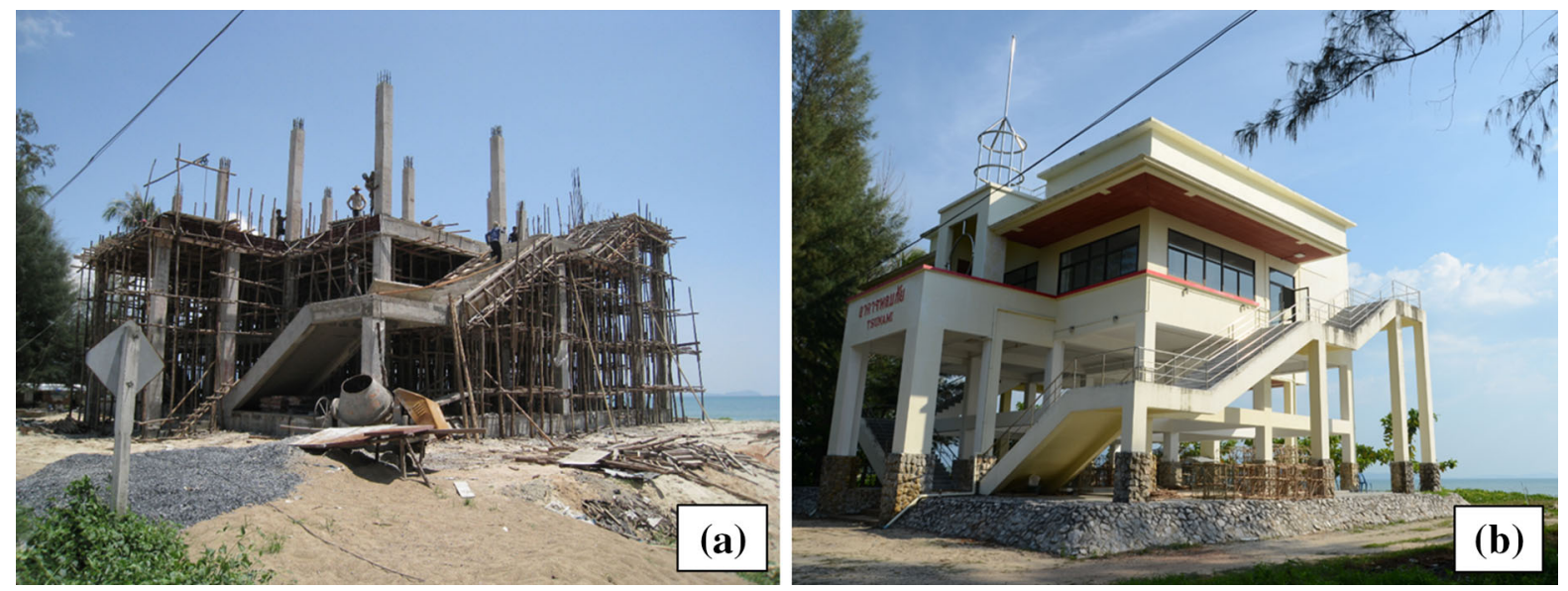

Figure 11

Tsunami evacuation building in Pakarang Cape (a) during construction in 2009 and (b) in 2013

numbers of tourists stay in the tsunami hazard zone or spend most of their time there. Although evacuation signs are located every 300, 200 and $100 \mathrm{~m}$ from the beach to the safe zone, some of them are not well maintained. Moreover, the evacuation route planned by the local government goes through private property and is full of shops and stalls that could lead to a difficult evacuation. The traffic jam in Patong was the most serious among the 2004 tsunami-affected areas. Traffic jams occur daily during rush hour in the morning and evening. One reason for these traffic jams is the large number of motorcycles that are rented by tourists. The three evacuation shelters comprise a school, a temple and a market. All of these shelters are located more than $1 \mathrm{~km}$ from the sea. The school appears to be the most suitable shelter because of its space and accessibility. The tsunami warning in 2012 (without a damaging tsunami) confirmed that this situation is very hazardous. The warning occurred during the peak traffic period. As a result, all traffic was at a standstill from the top of the mountain to the road along the beach, inside the 2004 tsunami inundation zone. Figures 13 and 14 show the one-way traffic routes in Patong beach, which extend 

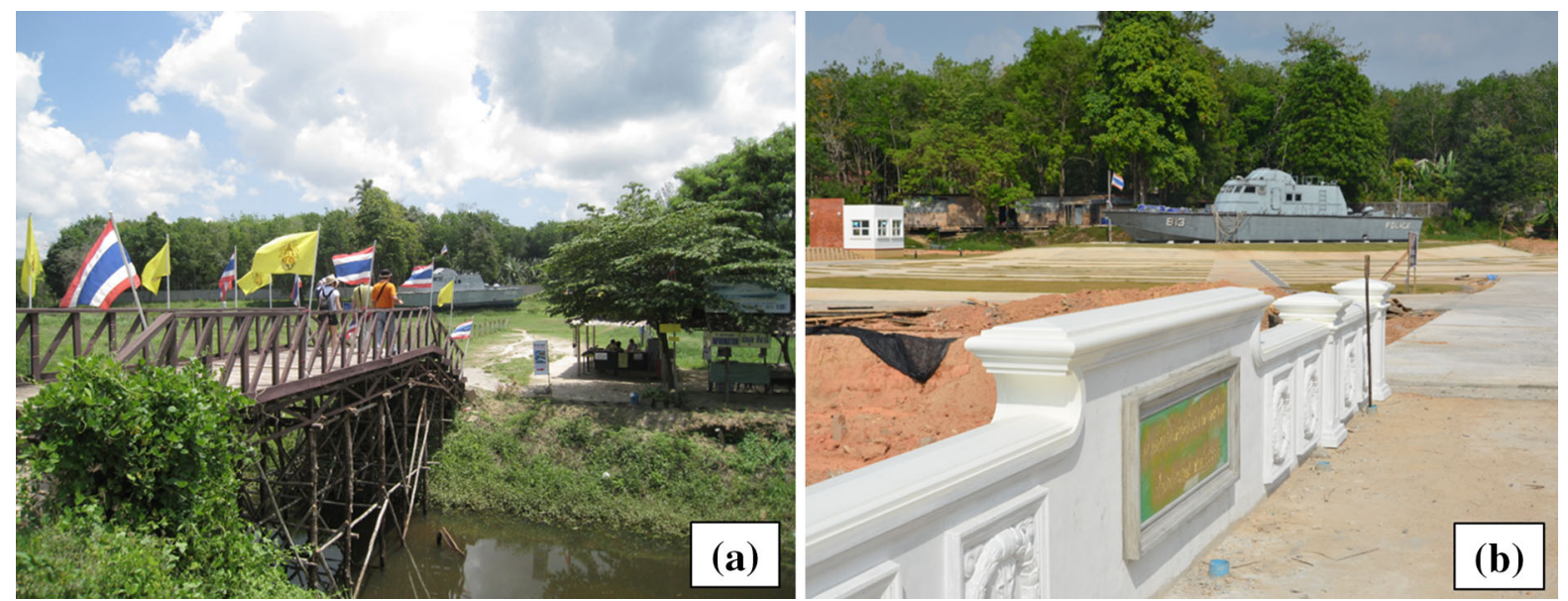

Figure 12

The T.813 patrol boat as a tsunami memorial (a) in 2009 and (b) in 2013

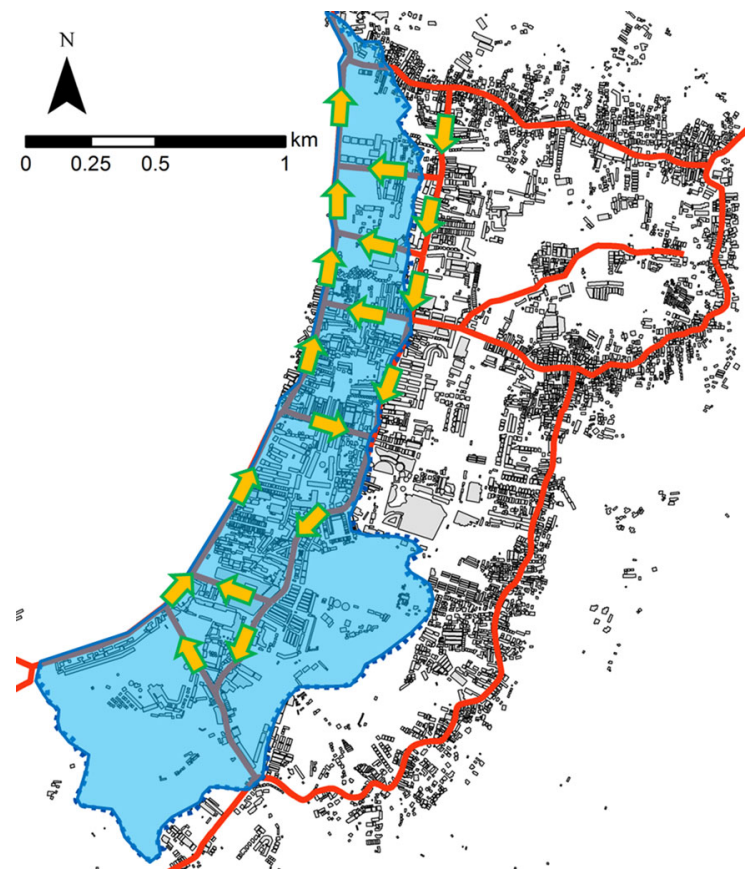

Figure 13

Map of Patong beach; the 2004 tsunami inundation depth (blue), buildings (gray), roads (red) and one-way traffic routes (arrows)

in a clockwise direction, going north along the shoreline and south on the inner road. Most of the small roads that link these two roads extend toward the sea except for one road that extends inland. The direction of these small roads is one of the reasons for the traffic jam, and the traffic rules during tsunami evacuations in Patong must be improved in preparation for future tsunamis.

\subsection{Geological and Environmental Changes}

\subsubsection{Tsunami boulders at Pakarang Cape}

The tsunami in 2004 transported thousands of meters-long boulders shoreward at Pakarang Cape, Thailand. Gото et al. (2007) investigated the size, position and long-axis orientation of 467 boulders on the cape. Most of the boulders found on the cape were well rounded, ellipsoid and without sharp, broken edges. They were fragments of reef rocks, and their sizes were estimated to be an average of $14 \mathrm{~m}^{3}$ (22.7 t). Gото et al. (2007) calculated the tsunami inundation at Pakarang Cape. They suggested that the tsunami waves, which were directed eastward, struck both reef rocks and coral colonies that were originally located on the shallow sea bottom near the reef edge; these detached, and the boulders were transported shoreward. During our visit in February 2013 (Fig. 15a), the boulders were still there. Conversely, sand accumulation was remarkable on the tidal bench, and the beach berm had quickly recovered. 

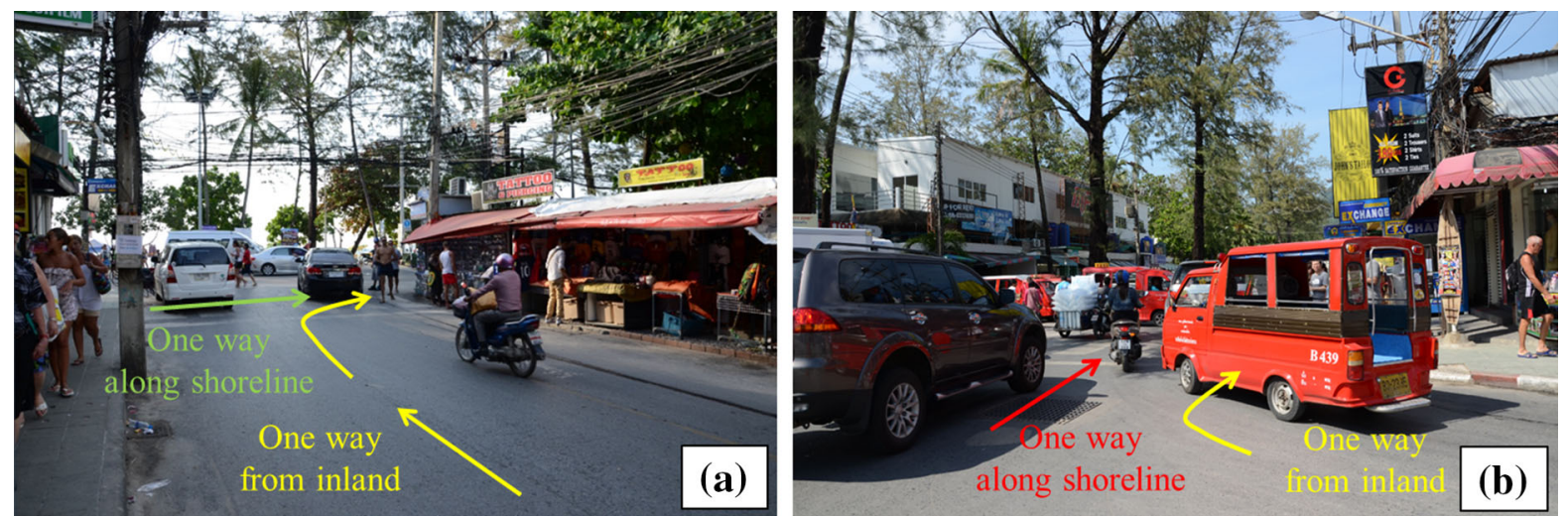

Figure 14

Traffic direction in Patong beach (a) in the south and (b) in the north
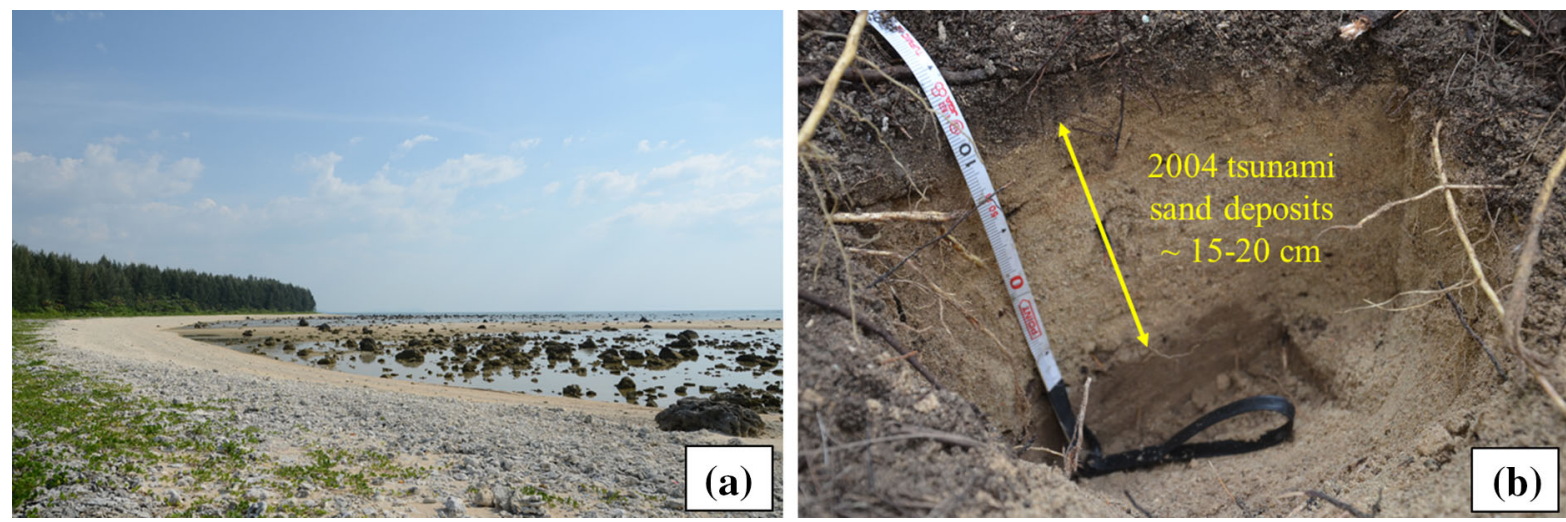

Figure 15

Remaining geological evidence at Pakarang Cape, a tsunami boulders and $\mathbf{b}$ tsunami sand deposits

\subsubsection{Tsunami Deposits in Bang Sak Beach}

JANKAEW et al. (2008) was the first group who discovered paleo-tsunami deposits prior to the 2004 event in Thailand. Although after a decade, there are well-preserved 2004 tsunami deposits on Bang Sak Beach. This area includes a beach and shallow marine sediments with abundant marine plankton. Gото et al. (2012a) conducted field surveys in March 2005 and December 2008 in southwestern Thailand to investigate local variation in the thickness and the preservation potential of onshore deposits formed by the 2004 tsunami. The 2008 survey results revealed that the thickness of deposits varied by a few centimeters in pits located less than $10 \mathrm{~m}$ apart because of the local undulation of the topography and possible bioturbation. At 13 of the 24 sites, the difference in thickness between the 2005 and 2008 surveys was within the range of local variation. In fact, very thin tsunami deposits $(1 \mathrm{~cm}$ thick) in the 2005 survey were well preserved during the 2008 survey. Furthermore, tsunami deposits near the maximum inundation limit were found in the 2008 survey, with thicknesses that were consistent with those reported in the 2005 survey. At no site was a tsunami deposit eliminated completely. Based on these observations, Gото et al. (2012a) inferred that tsunami deposits tend to be well preserved, even in a tropical climate with heavy rains, such as that of Thailand. Our visit in 2013 further supports the 
observation by Gото et al. (2012a), insofar as we observed that the deposits were well preserved in cases where there were no human disturbances (Fig. 12b).

\subsubsection{Mangrove Forests at Pakarang Cape}

Yanagisawa et al. (2009) investigated the damage to mangroves caused by the 2004 tsunami at Pakarang Cape. Comparing pre- and post-tsunami satellite imagery of the study area, they found that approximately $70 \%$ of the mangrove forest was destroyed by the tsunami. Based on field observations, they determined that the survival rate of mangroves increased with increasing stem diameter. Specifically, they found that $72 \%$ of Rhizophora trees with a $25-30 \mathrm{~cm}$ stem diameter survived the tsunami impact, whereas only $19 \%$ of the trees with a 15-20 cm stem diameter survived. After the tsunami, the mangrove forest was not replanted, and parts of the forest became resort areas.

\section{The Situation in the Maldives}

In comparison to other countries, such as Indonesia, Sri Lanka and Thailand, the Maldives experienced less damage not only because of their geological setting but mainly because of their geological features: the coral atolls with small islands separated by deep channels (FriTz et al. 2006). Even though the tsunami arrived $4 \mathrm{~h}$ after the Maldives, a $9 \mathrm{~m}$ runup resulted in 300 fatalities in Somalia (FrITZ and BorRero 2006). However, if we compare the displaced population with the total population of the Maldives, the damage was very significant. Although the elevation of the entire island chain is lower than $2 \mathrm{~m}$, the 26 December tsunami had a limited impact on the Maldives due to its unique geological features as mentioned earlier. In addition, because of the country's low elevation, the tsunami could completely overtop or submerge the island. Therefore, there was no runup process amplifying the tsunami as high as $8 \mathrm{~m}$ in Sri Lanka (Liu et al. 2005) and the maximum tsunami height observed in the Maldives was only up to $4.1 \mathrm{~m}$ (FriTz et al. 2006). A field visit to discuss the present countermeasures prepared by the central and local governments and to observe the present condition of the Maldives was held from 23 to 29 December 2013 with support from the Asian Disaster Reduction Center (ADRC).

\subsection{General Observations}

Male, the capital city (Fig. 16), with an area of $1 \times 2 \mathrm{~km}^{2}$, was the main target area for our official visits. The city was protected during the 1990s by seawalls and breakwaters (Fig. 17a) that were built before the 2004 tsunami; however, measures for supporting evacuation during future tsunamis were not observed. Unlike in Indonesia, Sri Lanka and Thailand, there were no tsunami-related signs to provide information on the tsunami hazard zone, the tsunami height, evacuation routes or evacuation buildings. On the 9-year anniversary of the tsunami (26 December 2013), there were no major events in Male except several news reports, but there were some small events on other islands. There was no sign indicating the tsunami memorial monument shown in Fig. 17b. This picture was taken on the anniversary, and the monument was no busier than on other days. The main road along the shoreline, which links the entire city, is a one-way street, similar to the roads in Patong beach in Phuket, Thailand. The two-lane road is always crowded with parked cars and motorcycles that could obstruct evacuation (Fig. 18a, b). The small streets that link the main road to the inland are narrow and obstructed by many objects on the ground. In addition, although most buildings along the shoreline have at least two stories, there are no signs indicating tsunami evacuation shelters. The coast guard building and other government buildings near the shoreline could be used as evacuation buildings.

\subsection{Central Government Offices}

Meetings with several offices of the central governmental were conducted to investigate the ongoing disaster risk reduction efforts of each organization-namely, the Maldives National Defense Force (MNDF), the Ministry of Education (ME), the Ministry of Tourism (MT), the Ministry of Housing and Infrastructure (MHI) and the Maldives Meteorological Service (MMS). 


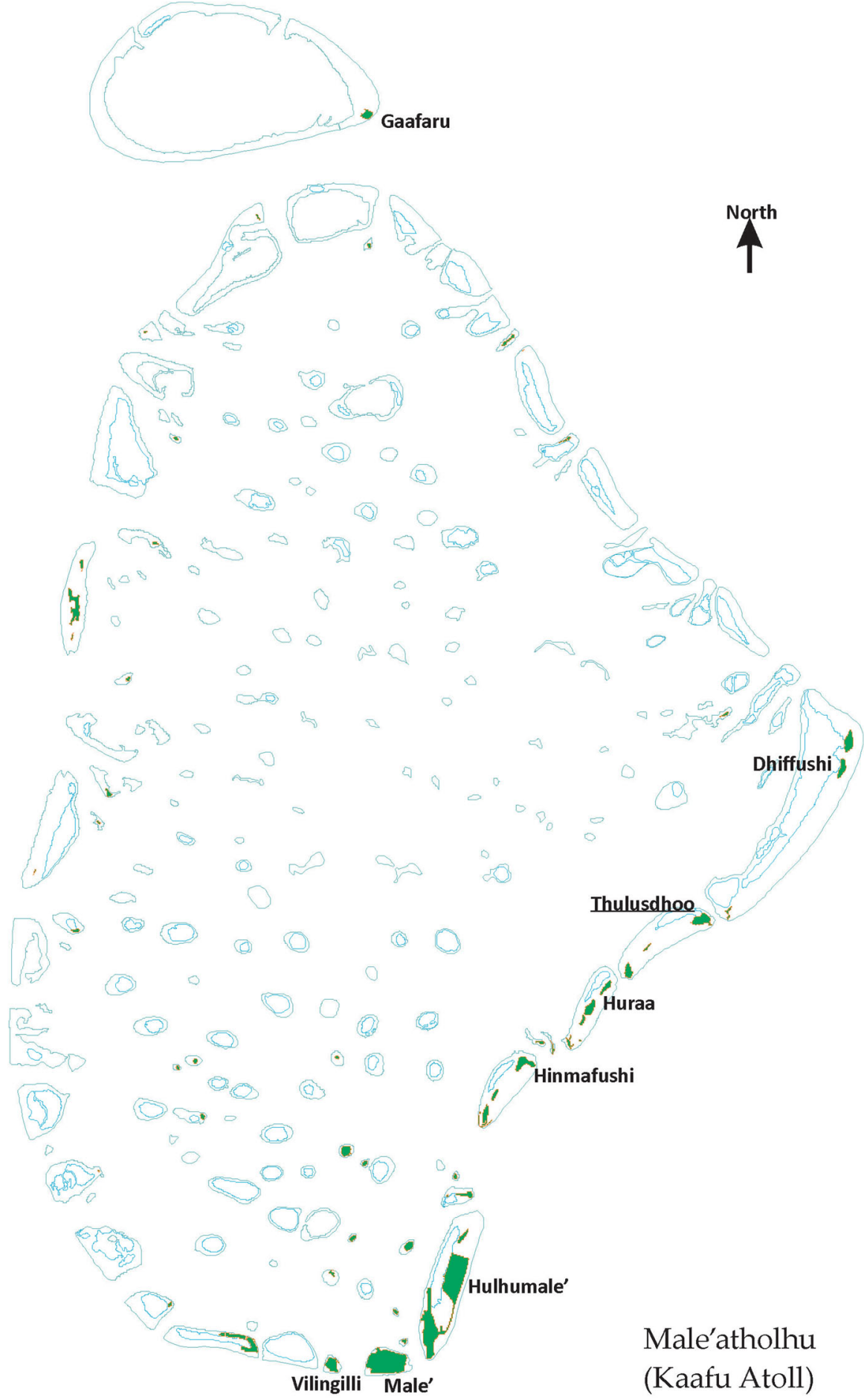

Male`Atoll showing inhabited island

Figure 16

Locations of atolls and islands in the Maldives mentioned in this study 

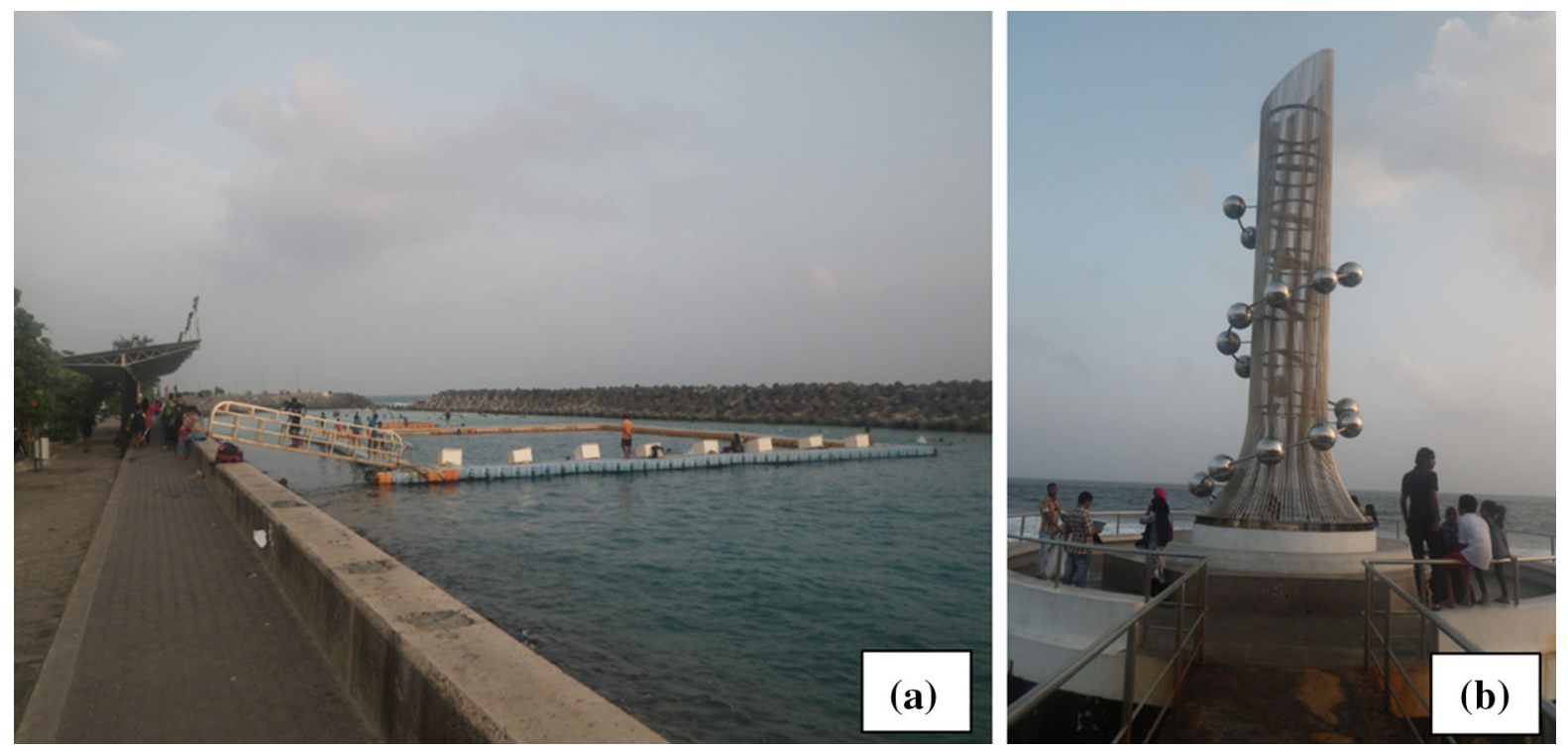

Figure 17

a Seawall and breakwater in the south of Male and $\mathbf{b}$ memorial statue of the 2004 Indian Ocean tsunami in Male
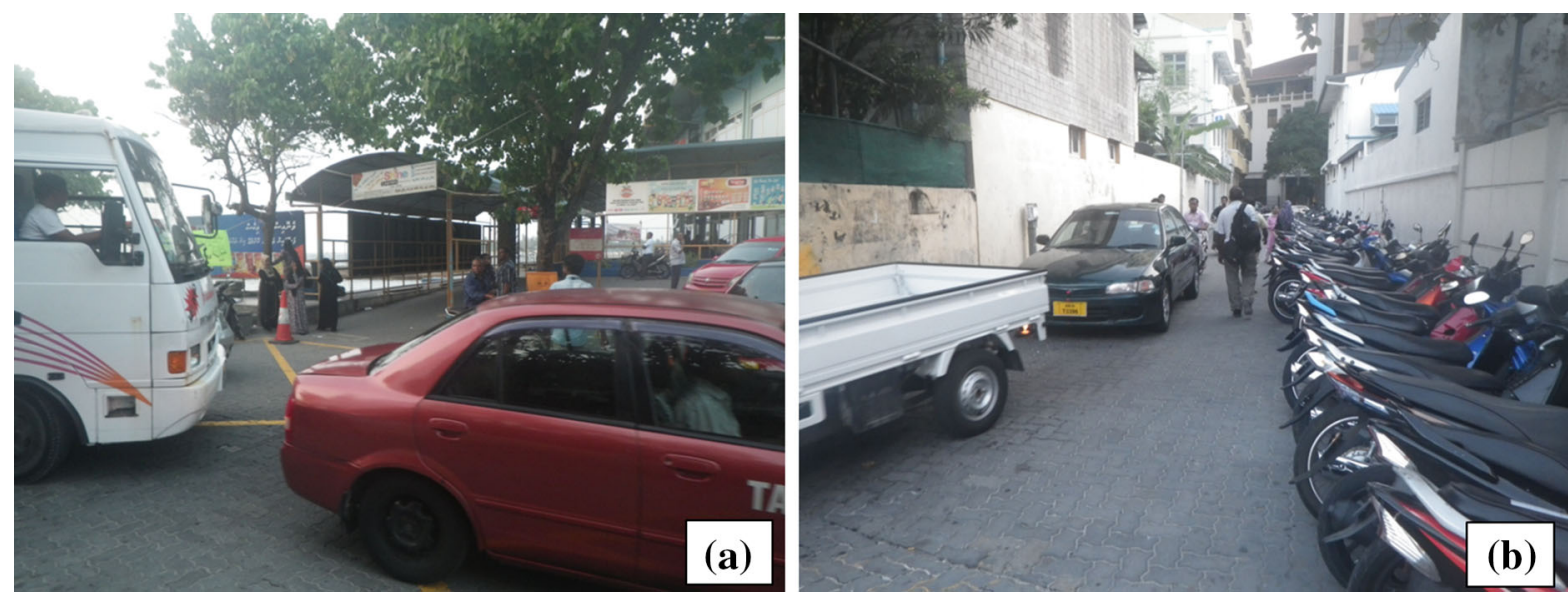

Figure 18

a Crowded traffic during rush hour in the road along the coast and $\mathbf{b}$ an evacuation route that is blocked by parked motorcycles

The MNDF is the most important of these agencies because it has the necessary manpower and facilities that can be used during an emergency. It would be one of the first teams to reach the affected areas to solve physical problems and support further activities. However, some of its assets that can be used in case of emergency, such as speed boats, seaplanes and helicopters, will encounter logistical problems because the country contains numerous islands and a limited budget for new assets. Response time is likely the most important factor in an emergency. The shorter the response time of the MNDF it, the more time that is available for other activities, such as the medical team response, the receipt of supporting materials and volunteer work. 
The ME is now attempting to implement a disaster-related curriculum in schools starting at the kindergarten level because children may have to lead adults to evacuate in future disasters. For example, during the 2004 tsunami in Thailand, a young British girl helped more than a hundred people evacuate and survive. The ministry is also adapting the teaching materials so that they will be interesting to children.

At present, good practices have been integrated into tourism-i.e., a brief introduction to disasterrelated information is provided at check-in at each resort. The MT considers the total exposed population (the local population plus the number of tourists) to be sustainable. Because tourism is the main economic sector in the country, the MT is now addressing any type of disaster that might interrupt tourism activities. Information related to disasters should also be well disseminated because tourists are more sensitive to the media, which mainly focus on bad news.

The MHI is the key ministry for long-term reconstruction insofar as its work is related to daily life. Some problems identified during the interview were (1) the lack of logistics for importing construction resources from nearby countries (e.g., India or the Middle East), (2) the lack of skilled manpower, (3) the necessity of group relocation to reduce construction costs for basic infrastructure and (4) the necessity of providing education to people who receive compensatory money but who spend it to meet different objectives. To solve one of these problems, the MHI is now encouraging children to relocate to bigger islands for a better education. If this occurs, parents must follow their children, and infrastructure construction costs can be reduced.

Although the MMS does not have its own warning system and must rely on other international services, the present warning and observation systems appear to be sufficient. In terms of tsunami warning, the MMS has a network linked to all four major institutions that take measurements in the Indian Ocean. Warning information from these institutions, such as the expected tsunami arrival time and amplitude, is sufficient for such short-term measures; however, for the long term, more detailed information, such as hazard maps for predicted future events, may be necessary. The warning dissemination method still appears to pose problems. A communication network and a commitment to use it during a disaster should be established to disseminate vital information, which should be made more easily understandable for less educated people.

\subsection{Relocated Residents and Local Stakeholders}

A field site visit was organized to observe and interview local residents and stakeholders. Thulusdhoo Island, the capital of the Kaafu Atoll, was selected as the target area because of its large proportion of relocated residents from other islands affected by the 2004 tsunami-340 out of the total population of 1361 on the island. The island is approximately $25 \mathrm{~km}$ northeast of Male. Typical disasters in Thulusdhoo Island are storm surges, floods and coastal erosion; however, the island was hit by waves 1-2 m high during the 2004 tsunami. After the tsunami, the government requested that some companies move off the island, and the factories were used as temporary shelters for 4 years. Figure 19a shows that the deserted areas remained the same for 9 years. New houses were constructed with donations from Saudi Arabia to those who used to own land before the tsunami, as shown in Fig. 19b.

The island is small, and the sea is a $5-10 \mathrm{~min}$ walk from the center of the island. There is only one reinforced concrete high-rise building (Fig. 20a) for tsunami evacuation on the island, which belongs to the MNDF. This building has speakers on the roof to issue warnings. During the day of our visit, we attended a disaster resilience workshop held by the MNDF in this building. Participants were asked to create an exposure map, a hazard map and an evacuation map for each type of hazard (Fig. 20b). Residents on this island appear to have a high awareness of disasters as a result of the 2004 tsunami.

Interviews were organized with the local residents who lost their houses in the 2004 Indian Ocean tsunami and relocated to Thulusdhoo Island. The government gave them a choice of three possible islands for their relocation. All of the residents are satisfied with their new homes, and they have better economic opportunities. Although 9 years have passed since the 2004 tsunami, residents still have a 

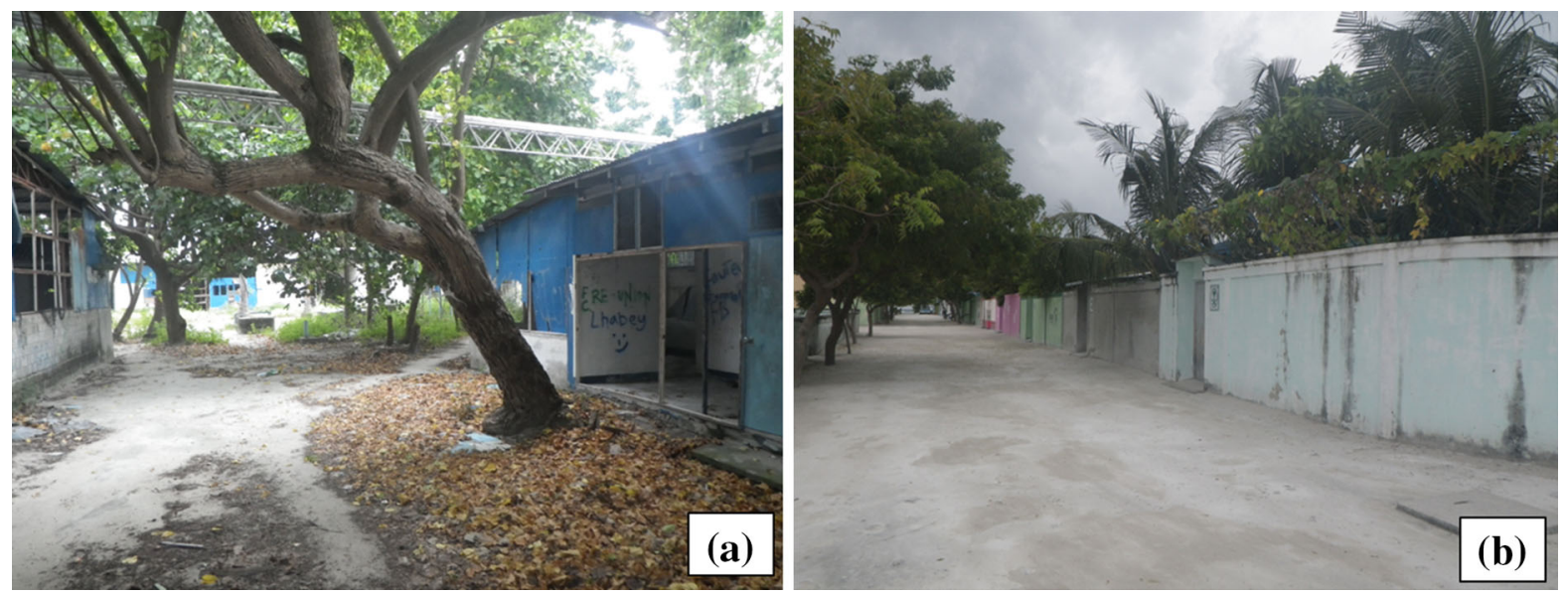

Figure 19

The present conditions of a deserted temporary shelters and $\mathbf{b}$ reconstructed houses in Thulusdhoo Island
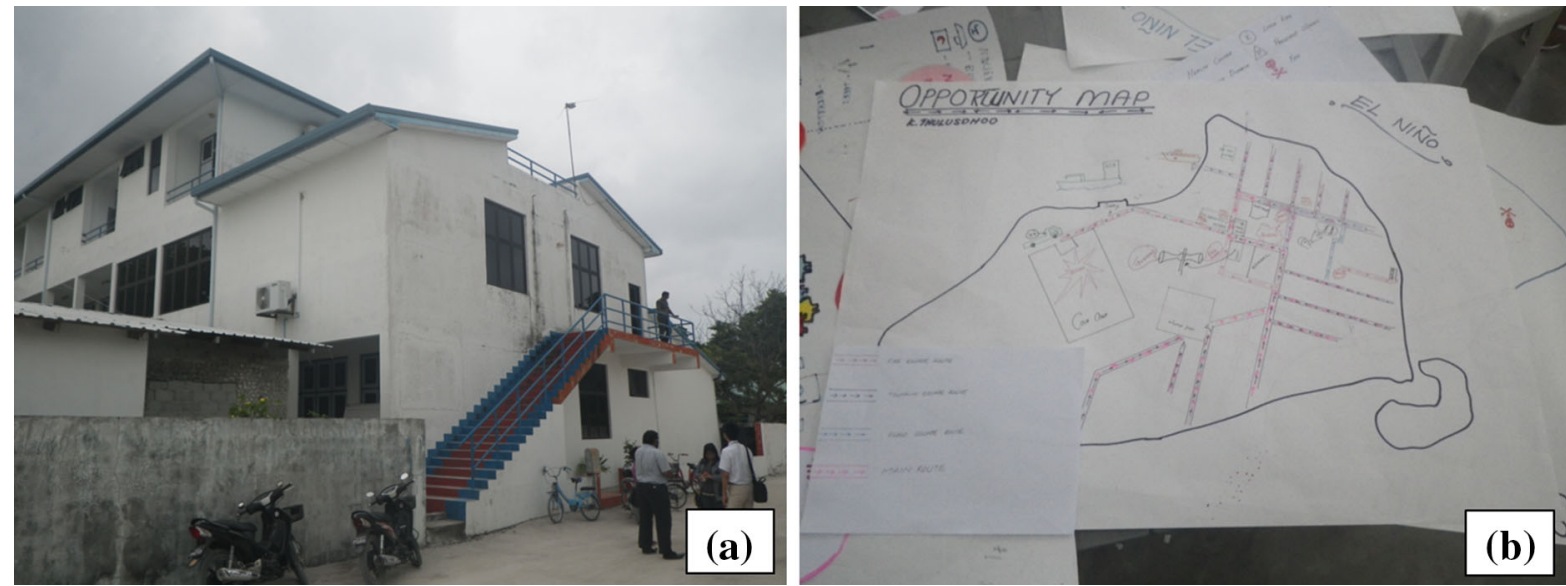

Figure 20

a The MNDF building and $\mathbf{b}$ an example of a tsunami evacuation route map made by residents in Thulusdhoo Island

high awareness and a strong will to participate in disaster-related activities. However, there has been a problem regarding the amount of space in residents' new houses. Because extended families commonly live together in this country, often one house with three rooms cannot accommodate the size of a household.

A meeting was organized with representatives from schools, health centers, the police force and the atoll council. Although the local people are satisfied with the present conditions, the stakeholders who attended the meeting are not because the facilities and infrastructure do not meet the standards to which the government had committed itself. The population size has been increasing, but the capacity of institutions such as schools and health centers has remained the same. In particular, the stakeholders indicated the need to upgrade the health center to a hospital. At the moment, there is still a lack of necessary medical equipment. These problems resemble those experienced in the areas mentioned in the previous section, where the country's geography makes it difficult for the central government to reach remote areas and provide support. 


\section{Conclusion}

Based on the findings obtained during our visits to the target countries, we identified the three key issues that reflect the preparedness of these areas and the future challenges that exist 10 years after the 2004 Indian Ocean tsunami. For this long interval event, it is necessary to prepare resilient communities for future generations monitoring such progress. In addition, the progress achieved in disaster preparedness after 3 years of reconstruction was compared to that achieved after 10 years and evaluated based on experience in disaster reconstruction in Japan.

\subsection{Town Reconstruction and Land Use Planning}

The countries in our study area were similar in terms of the installation of tsunami warning signs and the construction of tsunami evacuation shelters, which were constructed while town reconstruction was occurring. In general, the town reconstructions in most of the countries in our study were completed within a few years after the 2004 tsunami, except in the Maldives, where the logistics of obtaining building materials appeared to be the most important factor causing the delay. Improving the logistics system for a country that contains many islands is a challenge. In addition, the country contains a large number of small islands on coral atolls without building materials apart from the corals. In terms of land use planning, there have been no major changes in the popular sightseeing areas, such as those in Thailand and the Maldives. However, future disaster-related property loss is expected to be larger than that from the 2004 event along the Andaman coast of Thailand because that area is more exposed due to the larger number of hotels and resorts. In addition, serious traffic jams might occur similar to those experienced in 2012. For tourism-designated islands in the Maldives, where the number of tourists is significant, taking into account the expected number of tourists appears to be one of the most important measures for emergency response.

\subsection{Warning Systems and Emergency Response}

Tsunami warning services can be classified into three categories: (1) a regional service (Indonesia), (2) a national service (Thailand) and (3) the need for information from other regional service countries (the Maldives and Sri Lanka). After the 2004 tsunami, the Pacific Tsunami Warning Center (PTWC) acted as the center for tsunami warnings in the Indian Ocean for several years, but currently, this service is being provided by regional tsunami service providers in Australia, India and Indonesia and by other regional services, such as RIMES. Thailand has a national service provided by the NDWC. Sri Lanka and the Maldives do not have their own services, but they receive warning messages from the aforementioned regional service countries. This approach appears to be sufficient in terms of tsunami evacuation. A tsunami evacuation drill is performed yearly and simultaneously in all study areas to test their tsunami warning systems. Nevertheless, further research and development of tsunami-related topics, such as land use planning in preparation for future tsunamis using detailed probabilistic tsunami hazard maps and vulnerability functions, are needed.

\subsection{Disaster Reduction Education and Other Disaster-Awareness-Related Topics}

Disaster reduction education is an issue to which all countries in our study area gave considerable attention during the beginning stages of reconstruction. Basic knowledge of disasters was added to school curricula, and workshops and lectures were organized in cooperation with both national and international organizations. These efforts will help local people understand the meaning of warnings and the proper action to take during an evacuation. Furthermore, tsunami museums and tsunami memorials have been built in most locations. There are some differences among the countries; for example, Indonesia and Thailand succeeded in maintaining some marine vessels that were carried ashore as memorials, but this was not the case for the damaged train in Sri Lanka. Nevertheless, these attempts will help maintain awareness of the 2004 disaster. Geological 
evidence will also maintain people's awareness. The number of boulders that remains in Thailand is a good example for telling the story of the 2004 tsunami.

\subsection{Evaluation of the 2004 Affected Countries Using the Four Main Components of Disaster Reconstruction}

We further evaluated reconstruction after the 2004 Indian Ocean tsunami based on observations from our field visits using the four main components of disaster reconstruction [Disaster Prevention Research Institute (DPRI) 2004]. This type of longterm reconstruction plan is based on experience with historical disasters in Japan, including the 1611 Keicho-Sanriku tsunami and the 1854 Ansei-Nankai tsunami. The four components are described below.

1. Town reconstruction and planning (Living): town and regional planning conducted alongside housing reconstruction.

2. Self-reliance and linkage (Communication): communication during normal and emergency periods among local residents, their self-reliance, the linkages among them and evacuation drills.

3. Community and local industry formation (Occupation): recovery of local industries and related facilities.

4. Disaster education and culture (Experience transfer): Maintenance of disaster awareness and research on disaster observations and assessments.

Our evaluations of the early-stage reconstruction period (within three years after the 2004 tsunami, as introduced in Sect. 2, and reconstruction after a decade, as discussed in Sects. 4, 5, 6, 7, are shown in Tables 1 and 2, respectively.

Using three symbols and their accompanying definitions-( - ) ongoing, (ム) existing with some limitations, and (-) well-prepared-and Thailand as an example, explanations are presented below.

1. Town reconstruction and planning: $(\mathbf{\Lambda}) \rightarrow(\boldsymbol{\Lambda})$

The reconstruction of houses and hotels was completed in most areas during the first stage, but problems with evacuation routes and disaster zoning remain after 10 years.

Table 1

Evaluation of the 2004 tsunami-affected countries using the four main components of disaster reconstruction [after 3 years (i.e., the earlystage reconstruction period): Sect. 2]

\begin{tabular}{|c|c|c|c|c|}
\hline \multirow[b]{2}{*}{ Four components } & \multicolumn{4}{|c|}{ The 2004 Indian Ocean tsunami-affected countries } \\
\hline & Indonesia & Sri Lanka & Thailand & $\begin{array}{c}\text { The } \\
\text { Maldives }\end{array}$ \\
\hline Town reconstruction and planning & $\boldsymbol{\Delta}$ & $\boldsymbol{\Delta}$ & $\boldsymbol{\Delta}$ & - \\
\hline Self-reliance and linkage & - & $\Delta$ & $\Delta$ & $\Delta$ \\
\hline Community and local industry formation & $\Delta$ & $\Delta$ & $\Delta$ & - \\
\hline Disaster education and culture & - & - & - & - \\
\hline
\end{tabular}

(一) Ongoing, ( $\mathbf{\Delta})$ exists with some limitations,

) well prepared

Table 2

Evaluation of the 2004 tsunami-affected countries using the four main components of disaster reconstruction (after a decade: Sects. 4, 5, 6, 7)

\begin{tabular}{|l|c|c|c|c|}
\hline \multirow{2}{*}{ Four components } & \multicolumn{3}{|c|}{ The 2004 Indian Ocean tsunami-affected countries } \\
\cline { 2 - 5 } & Indonesia & Sri Lanka & Thailand & $\begin{array}{c}\text { The } \\
\text { Maldives }\end{array}$ \\
\hline Town reconstruction and planning & $\boldsymbol{\Delta}$ & $\boldsymbol{\Delta}$ & $\boldsymbol{\Delta}$ & $\boldsymbol{\Delta}$ \\
\hline Self-reliance and linkage & $\boldsymbol{\Delta}$ & $\bullet$ & $\bullet$ & $\boldsymbol{\Delta}$ \\
\hline Community and local industry formation & $\bullet$ & $\bullet$ & $\bullet$ & $\boldsymbol{\Delta}$ \\
\hline Disaster education and culture & $\mathbf{\Delta}$ & $\mathbf{\Delta}$ & $\mathbf{\Delta}$ & $\mathbf{\Delta}$ \\
\hline
\end{tabular}

$(\mathbf{\Delta}) \rightarrow(\mathbf{\Delta})$ Ongoing, $(\mathbf{\Delta}) \rightarrow(\bullet)$ exists with some limitations, $(-) \rightarrow(\mathbf{\Delta})$ well prepared 
2. Self-reliance and linkage: $(\boldsymbol{\Lambda}) \rightarrow(\bullet)$

The performance of tsunami warnings has been improved from 20 min after earthquake occurrence during the early stage of NDWC reconstruction to less than $5 \mathrm{~min}$ after a decade. Evacuation drills are organized every year and receive positive feedback and cooperation from local residents.

3. Community and local industry formation: $(\mathbf{\Lambda}) \rightarrow(\bullet)$ The recovery of hotels and other tourism-related businesses was completed in most areas a few years after the tsunami, and they were fully operational after 10 years.

4. Disaster education and culture: $(\rightarrow) \rightarrow(\mathbf{\Lambda})$

During the early stage, a framework for disaster education was applied in some university-level curricula, but not at the lower pre-university levels. Some damaged structures were preserved as tsunami monuments, but most of these have been poorly maintained.

We hope that our evaluation results will be used as indicators for a regional comparative study of disaster reconstruction and that they can be applied to evaluate progress in disaster preparedness for other disaster events in the future.

\section{Acknowledgments}

Dr. Anawat Suppasri would like to express sincere gratitude to ADRC for supporting his trip to the Maldives and to TMD and RIMES for their local support. Dr. Prasanthi Ranasinghe would like to convey her gratitude to the Lanka Hydraulic Institute Ltd (LHI) for providing literature that contributed to the Sri Lankan section. This research was funded by the Reconstruction Agency of the Government of Japan and Tokio Marine \& Nichido Fire Insurance Co., Ltd. through IRIDeS, Tohoku University. The authors greatly appreciate Dr. Hermann M. Fritz, guest editor, two anonymous reviewers and Joshua Macabuag from University College London for valuable comments on the entire paper.

Open Access This article is distributed under the terms of the Creative Commons Attribution 4.0 International License (http:// creativecommons.org/licenses/by/4.0/), which permits unrestricted use, distribution, and reproduction in any medium, provided you give appropriate credit to the original author(s) and the source, provide a link to the Creative Commons license, and indicate if changes were made.

\section{REFERENCES}

AlJAZEera News (2012) Indian Ocean on tsunami alert after quakes http://www.aljazeera.com/news/asia-pacific/2012/04/ 201241185126462944.html (Accessed 25 March 2014)

Amateur Seismic Center (ASC) (2005) M8.7 Nias-Simeulue Earthquake, 2005 http://www.asc-india.org (Accessed 25 March 2014)

Asian Development Bank (ADB) (2005), Japan Bank for International Cooperation and World Bank, Preliminary Damage and Needs Assessment-2005 Post Tsunami Recovery Program, Sri Lanka.

Bauman, P., Ayalew, M. and Paul, G. (2007) Beyond disaster: Comparative analysis of tsunami interventions in Sri Lanka and Indonesia/Aceh, Journal of Peacebuilding and Development, 3 (3), 6-21.

BBC News (2007) Powerful quake shakes Indonesia http://news. bbc.co.uk/2/hi/asia-pacific/6991134.stm (Accessed 25 March 2014)

Borrero, J. C., McAdoo, B., Jaffe, B., Dengler, L.,Gelfenbaum, G., Higman, B., Hidayat, R., Moore, A., Kongko, W., Lukijanto, Peters, R., Prasetya, G., Titov, V. Yulianto, E. (2011) Field survey of the March 28, 2005 Nias-Simeulue earthquake and tsunami, Pure and Applied Geophysics, 168, 6-7, 1075-1088.

Borrero, J. C., Weiss, R., Okal, E. A., Hidayat, R., Suranto, ARcas, D. and Titov, V. (2009) The tsunami of 2007 September 12, Bengkulu province, Sumatra, Indonesia: post-tsunami field survey and numerical modeling, Geophysical Journal International, 178 (1), 180-194.

Borrero, J. C., Synolakis, C. E. and Fritz, H. (2006) Northen Sumatra field survey after the December 2004Great Sumatra earthquake and Indian Ocean tsunami, Earthquake Spectra, 22 (S3), 93-104.

Burbidge, D., Cummins, P. R., Mleczko, R. and Thio, H. K. (2008) Probabilistic tsunami hazard assessment for Western Australia, Pure and Applied Geophysics, 165, 2059-2088.

CH2MHiLl and Lanka Hydraulic Institute Ltd (2006) Main report of Fish Harbor Repairs and Improvements-Preliminary Assessment Report-February 2006, Sri Lanka Tsunami Reconstruction Program,1-8.

Diposaptono, S., A. Muhari, F. Imamura, S. Koshimura and H. YANAGISAWA (2013). Impacts of the 2011 East Japan tsunami in the Papua region, Indonesia: field observation data and numerical analyses. Geophysical Journal International, Volume 194, Issue 3, p.1625-1639

Disaster Prevention Research Institute (DPRI) (2004) Handbook of disaster prevention science, Edited by DPRI, Kyoto University, $2^{\text {nd }}$ Edition, Asakura publishing, 724 pp. ISBN 4-254-26012-1 C3051

EniA, J. S. (2008) Peach in its wake? The 2004 tsunami and internal conflict in Indonesia and Sri Lanka, Journal of Public \& International Affairs 19(1): 7-27.

Franco, G., Sheth, A. and Meyer M. (2013) Observations on the Recovery and Reconstruction in Sri Lanka Following the December 26, 2004 Tsunami, An Earthquake Engineering Research Institute (EERI) Field Report, 44 pp. 
Fritz, H.M., J.C. Borrero (2006). Somalia field survey of the 2004 Indian Ocean Tsunami. Earthquake Spectra 22(S3):S219-S233.

Fritz, H. M., Synolakis, C. E. and McAdoo, B. G. (2006) Maldives field survey after the December 2004 Indian Ocean tsunami, Earthquake Spectra, 22, S3, S137-S154.

Geist E., Kirby, S., Ross, S. and Dartnell, P. (2009) Samoa disaster highlights danger of tsunamis generated from outer-rise earthquakes, Sound Waves, Coastal and Marine Research News from Across the USGS, December 2009. Available at: http:// soundwaves.usgs.gov/2009/12/research.html (Accessed date: 30 May 2015)

Goff, J., Liu, P.L.-F., Higman, B., Morton, R., Jaffe, B.E., Fernando, H., Lynett, P., Fritz, H., Synolakis, C. (2006). The December 26th 2004 Indian Ocean tsunami in Sri Lanka. Earthquake Spectra 22(S3):S155-S172.

Goto, K., Chavanich, S. A., Imamura, F., Kunthasap, P., Matsui, T., Minoura, K., Sugawara, D., Yanagisawa, H. (2007) Distribution, origin and transport process of boulders transport by the 2004 Indian Ocean tsunami at Pakarang Cape, Thailand. Sedimentary Geology, Vol. 202, 821-837

Goto, Y., Ogawa, Y. and Komura, T. (2010) Tsunami disaster reduction education using town watching and moving tsunami evacuation animation-Trial in Banda Aceh, Journal of Earthquake and Tsunami, 4 (2), 115-126.

Goto, K., Takahashi, J., OIE, T., Imamura, F. (2011) Remarkable bathymetric change in the nearshore zone by the 2004 Indian Ocean tsunami: Kirinda Harbor, Sri Lanka. Geomorphology 127 (1-2), 107-116.

Goto, K., Takahashi, J., Fujino, S. (2012a) Variations in the 2004 Indian Ocean tsunami deposits thickness and their preservation potential, southwestern Thailand. Earth, Planets and Space, Vol. 64, 923-930.

Goto, Y., Affan, M., Agussabti, Nurdin, Y., Yuliana, D. and ARdiANSYAH (2012b) Tsunami evacuation simulation for disaster education, Journal of Disaster Research, 7 (1), 92-101.

Goto, Y., Affan, M. and Fadli (2012c) Response of the People in Banda Aceh just after the 2012 April 11 Off-Sumatra Earthquake (M8.5), Quick report, Syiah Kuala University, 16 pp.

Hill, E.M., J.C. Borrero, Z. Huang, Q. Qiu, P. Banerjee, D.H. Natawidjaja, P. Elosegui, H.M. Fritz, B.W. Suwargadi, I.R. Pranantyo, L. Lin, K.A. Macpherson, V. Skanavis, C.E. SynoLAKIS, and K. SIEH (2012). The 2010 Mw 7.8 Mentawai earthquake: Very shallow source of a rare tsunami earthquake determined from tsunami field survey and near-field GPS, J. Geophys. Res. Solid Earth, 117, B06402.

Hyndman J. (2009) Siting Conflict and Peace in Post-Tsunami Sri Lanka and Aceh, Indonesia, Norwegian Journal of Geography 63.1 (2009): 89-96.

Imamura, F. (2008) Dissemination of Information and Evacuation Procedures in the 2004-2007 tsunamis, including the 2004 Indian Ocean, Journal of Earthquake and Tsunami, 3(2), 59-65.

Jaffe, B., Borrero, J. C., Prasetya, G. S., Peters, R., McAdoo, B., Gelfenbaum, F., Morton, R., Ruggiero, P., Higman, B., DenGler, L., Hidayat, R., Kingsley, E., Kongko, W., Moore, A., Titov, V. and Yulianto, E. (2006) Northwest Sumatra and offshore islands field survey after the December 2004 Indian Ocean tsunami, Earthquake Spectra, 22 (S3), 105-135.

Jankaew, K., Atwater, B. F., Sawai, Y., Choowong, M., Charoentitirat, T., Martin, M. E. and Prendergast, A. (2008) Medieval forewarning of the 2004 Indian Ocean tsunami in Thailand, Nature, 455, 1228-1231.
Kunn, R. (2009) Tsunami and conflict in Sri Lanka, The World Bank-UN Project report on the economics of disaster risk reduction, $41 \mathrm{pp}$.

Kuwata, Y. and TaKada, S. (2010) Business restoration related to lifeline after tsunami disaster, Journal of Earthquake and Tsunami, 4 (2), 73-82.

Kuwata, Y. (2011), Post-Tsunami Lifeline Restoration and Reconstruction, Tsunami-A Growing Disaster, Prof. Mohammad Mokhtari (Ed.), ISBN: 978-953-307-431-3, InTech

Khazai, B., Franco, G., Ingram, J. C., Rumbaitis del Rio, C., Dias, P., Dissanayake, R., Chandratilake, R., and Kanna, S. J., (2006). Post-December 2004 tsunami reconstruction in Sri Lanka and its potential impacts onfuture vulnerability, Earthquake Spectra, 22 (S3), 829-844.

Latief, H., Sengara, I. W. and Kusuma, S. B. (2008) Probabilistic seismic and tsunami hazard analysis model for input to tsunami warning and disaster mitigation strategies, Int. Conf. Tsunami Warning (ICTW) Bali, Indonesia.

Liu, P.L.-F., Lynett, P., Fernando, J., Jaffe, B.E., Fritz, H.M., Higman, B., Morton, R., Goff, J., Synolakis, C.E. (2005). Observations by the International Tsunami Survey Team in Sri Lanka, Science 308(5728):1595.

Løvholt, F., Bungum, H., Harbitz, C. B., Glimsdal, S. Lindholm, C. D. and Pedersen, G. (2006) Earthquake related tsunami hazard along the western coast of Thailand, Natural Hazards and Earth System Sciences, 6, 979-997.

Lauteruung, J., Münch, U., and Rudloff, A. (2010). The challenge of installing a tsunami early warning system in the vicinity of the Sunda Arc, Indonesia, Nat. Hazards Earth Syst. Sci., 10, 641-646.

Mas, E., Koshimura, S., Imamura, F., Suppasri, A., Muhari, A. and Adriano, B. (2015) Recent advances on agent based tsunami evacuation simulation. Case studies at Indonesia, Thailand, Japan and Peru, Pure and Applied Geophysics, (in this issue)

Ministry of Environment, Energy and Water (2007) National adaptation program of action-Republic of Maldives, $114 \mathrm{pp}$. Available online at: http://unfccc.int/resource/docs/napa/mdv01. pdf

Monecke, K., Finger, W., Klarer, D., Kongko, W., McAdoo, B. G., Moore, A. L. and Sudrajat, S. U. (2008) A 1,000-year sediment record of tsunami recurrence in northern Sumatra, Nature 455, 1232-1234.

Münch, U., Rudloff, A. and Lauteruung, A. (2011). Postface "The GITEWS Projec-results, summary and outlook", Nat. Hazards Earth Syst. Sci., 11, 765-769

Murao, O. and Nakazato, H. (2010) Recovery curves for housing reconstruction in Sri Lanka after the 2004 Indian Ocean tsunami, Journal of Earthquake and Tsunami, 4 (2), 51-60.

Mikami, T., Shibayama, T., Esteban, M., Ohira, K., J. Sasaki,T., Suzuki, H., Achiari, H., Widodo, T. (2014). Tsunami vulnerability evaluation in the Mentawai Islands based on the field survey of the 2010 tsunami, Nat. Hazards, 71, 851-870.

Muhari, A., and Imamura, F. (2014). When to cancel tsunami warning? a comprehensive review from the recent tsunamis in Indian Ocean and Pacific Ocean, Input paper for the Global Assessment Report (GAR) on Disaster Risk Reduction 2015. Available on http://www.preventionweb.net/english/hyogo/gar/ 2015/en/home/documents.html

NOAA National Geophysical Data Center (NGDC) (2014) Tsunami Event Database http://www.ngdc.noaa.gov/nndc/struts/ form? $\mathrm{t}=101650 \& \mathrm{~s}=70 \& \mathrm{~d}=7$ (accessed 25 March 2014) 
Oak Ridge National Laboratory (2006) LandScan 2006, Available at http://www.ornl.gov/sci/gist/landscan/landscan2006/.

OKal, E.A., H.M. Fritz, P.E. RaAd, C.E. Synolakis, Y. Al-ShidBi, and M. AL-SAIFI (2006a) Oman field survey after the December 2004 Indian Ocean tsunami, Earthquake Spectra, 22, S203-S218.

Okal, E.A., H.M. Fritz, R. Raveloson, G. Joelson, P. Pancoskova, and G. Rambolamanana (2006b) Madagascar field survey after the December 2004 Indian Ocean tsunami, Earthquake Spectra, 22, S263-S283, 2006.

OKal, E.A., A. Sladen, and E.A.-S. OкаL (2006c) Rodrigues, Mauritius and Réunion Islands, field survey after the December 2004 Indian Ocean tsunami, Earthquake Spectra, 22, S241-S261.

ОкаL, E.A., and C.E. Synolakis (2008) Far-field tsunami hazard from mega-thrust earthquakes in the Indian Ocean, Geophys. J. Intl., 172, 995-1015.

Pariatmono (2012). The Influence of Mentawai Tsunami to Public Policy on Tsunami Warning in Indonesia, Journal of Disaster Research, 7(1), 102-106.

Ranasinghe, D. P. L., Goto, K.., Takahashi, T., Takahashi, J., Wijethunge, J. J., Nishinata, T. and Imamura, F. (2013) Numerical assessment of bathymetric changes caused by the 2004 Indian Ocean tsunami at Kirinda Fishery Harbor, Sri Lanka, Coastal Engineering 81(2013), 67-81.

Riyaz, M. and Park, K. H. (2010) "Safer Island Concept" developed after the 2004 Indian Ocean tsunami: A case study of Maldives, Journal of Earthquake and Tsunami, 4 (2), 135-143.

Ruangrassamee, A., Yanagisana, H., Foytong, P., Lukkunaprasit, P., Koshimura, S., and Imamura, F., (2006). Investigation of tsunami-induced damage and fragility of buildings in Thailand after the December 2004 Indian Ocean tsunami, Earthquake Spectra, 22(S3), 377-401.

SAmek, J.H., Skole, D.L., Chomentowski, W (2004). Assessment of impact of the December 26, 2004 tsunami in Aceh Province Indonesia. Center for global change and earth observations. Available at http://www.landsat.org/trfic/tsunami2004/ Assessment_of_Tsunami04.pdf

Satake, K., Nishimura, Y., Putra, P. S., Gusman, A. R., Sunendar, H., Fuji, Y., Tanioka, Y., Latief, H. and Yulianto, E. (2013) Tsunami source of the 2010 Mentawai, Indonesia earthquake inferred from tsunami field survey and waveform modeling, Pure and Applied Geophysics, 170 (9-10), 1567-1582.

SiRIPONG, A. (2010) Education for disaster risk reduction in Thailand, Journal of Earthquake and Tsunami, 4 (2), 61-72.

Stein, S., and OкаL, E. A., (2005). Size and speed of the Sumatra earthquake, Nature, 434, 581-582.

Stein, S., and E. A., OKAL, Ultra-long period seismic study of the December 2004 Indian Ocean earthquake and implications for regional tectonics and the subduction process (2007) Bull. Seismol. Soc. Amer., 97, S279-S295, 2007.

Suppasri, A. (2010). Tsunami Risk Assessment to Coastal Population and building in Thailand. $\mathrm{PhD}$ thesis. Tohoku University.

Suppasri, A., Imamura, F. and Koshimura, S. (2012a) Tsunami hazard and casualty estimation in a coastal area that neighbors the Indian Ocean and South China Sea, Journal of Earthquake and Tsunami, 6(2), 1250010.
Suppasri, A., Muhari, A., Ranasinghe, P., Mas, E., Shuto, N., Imamura, F. and Koshimura, S. (2012b) Damage and reconstruction after the 2004 Indian Ocean tsunami and the 2011 Great East Japan tsunami, Journal of Natural Disaster Science, 34 (1), 19-39.

SynOLAKIS, C. E., and KonG, L., (2006) Runup measurements of the December 2004 Indian Ocean tsunami, Earthquake Spectra, 22 (S3), 67-91.

Takada, S., Kuwata, Y. and Pinta, A. (2010) Damage and reconstruction of lifelines in Phang Nga province, Thailand after the 2004 Indian Ocean earthquake and tsunami, Journal of Earthquake and Tsunami, 4 (2), 83-94.

Tomita, T., Arikawa, T., Kumagai, K., Tatsumi, D. and Yeom, G. S. (2011) Field survey on the 2010 Mentawai tsunami disaster, technical note of the port and airport research institute, Japan, No. 1235,26 p.

The Telegraph (2010) Indonesian tsunami warning system 'was not working'http://www.telegraph.co.uk/news/worldnews/asia/ indonesia/8090377/Indonesian-tsunami-warning-system-wasnot-working.html (accessed 27 October 2010)

Udo, K., Tanaka, H., Mano, A., Takeda, Y., 2013. Beach morphology change of southern Sendai coast due to 2011 Tohoku Earthquake Tsunami. Journal of Japan Society of Civil Engineers Series B2 69, I1391-I1395. (In Japanese with English abstract)

US Geological SuRvey (USGS) (2005) M8.7 Northern Sumatra Earthquake of 28 March $2005 \mathrm{ftp} / /$ hazards.cr.usgs.gov/maps/ sigeqs/20050328/20050328.pdf (accessed 25 March 2014)

US Geological SuRvey (USGS) (2007) Magnitude 8.5 - SOUTHERN SUMATRA, INDONESIA http://earthquake.usgs.gov/earthquakes/ eqinthenews/2007/us2007hear/ (accessed 25 March 2014)

US Geological Survey (USGS) (2012) M8.6 and M8.2 Northern Sumatra, Indonesia Earthquakes of 11 April 2012 ftp://hazards. cr.usgs.gov/maps/sigeqs/20120411/20120411.pdf (accessed 25 March 2014)

WiJetunge, J.J., (2009). Fieldmeasurements and numerical simulations of the 2004 tsunami impact on the south coast of Sri Lanka. Ocean Engineering 36, 960-973.

Wijayaratna, N., Ranasinghe, D.P.L., Jayanthiran, A., WeerAKKodi, C.M. and WiJesena, W.M.N. (2006) Hazard Map as a Means of Tsunami Disaster Mitigation in Galle, Sri Lanka, Proceedings of the International Conference on Tsunami Storm Surge \& other Coastal Disasters in Colombo, Sri Lanka.

Weiss, R. and BAhlburg, H., (2006). The coast of Kenya field survey after the December 2004 Indian Ocean tsunami, Earthquake Spectra, 22(S3), 235-240.

Yanagisama, H., Koshimura, S., Goto, K., Miyagi, T., Imamura, F., Ruangrassamee, A., and Tanavud, C., 2009, The reduction effects of mangrove forest on a tsunami based on field surveys at Pakarang Cape, Thailand and numerical analysis. Estuarine, Coastal and Shelf Science, Vol. 81, 27-37.

Yasuda, M., Imamura, F. and SupPasRi, A. (2014) Practical application of disaster education for children in Japan, in Proceedings of the international seminar of the 10 years commemoration of the 2004 Indian Ocean tsunami, Jakarta, Indonesia 24-27 November 2014. 